\title{
COMMON SENSE EN EL PENSAMIENTO INDEPENDENTISTA DE MIER
}

\author{
Alicia Tecuanhuey Sandoval \\ Benemérita Universidad Autónoma de Puebla \\ Carlos Eduardo Rivas Granados \\ Benemérita Universidad Autónoma de Puebla
}

\section{INTRODUCCIÓN}

En este artículo nos proponemos analizar con detenimiento la presencia de Thomas Paine (1737-1809) en las formulaciones de Servando Teresa de Mier (1765-1827) sobre la independencia de Nueva España. ${ }^{1}$ Hay reflexiones de Paine que aparecen en dos obras políticas de Mier: Historia de la Revolución en Nueva España, antiguamente Anábuac, que vio la luz en 1813, y Memoria político-instructiva, publicada en 1821. Mier usó en tales escritos un texto específico: Common Sense. Nos interesa observar los variados usos que Mier hizo de la obra de Paine

Fecha de recepción: 6 de julio de 2016

Fecha de aceptación: 18 de enero de 2017

${ }^{1}$ Este artículo se inserta dentro de la LGC Historia política mexicana del siglo XIX que venimos cultivando. Desarrolla un aspecto de la tesis de maestría de Rivas Granados, "Influencia del pensamiento", 2014, elaborada bajo la dirección de Alicia Tecuanhuey Sandoval. 
en ambos escritos, distanciados en el tiempo por ocho años de reflexiones y acción política, para preguntamos si las variaciones en el uso de las ideas de Paine fueron dos momentos en la evolución del pensamiento político de Mier o fueron formulaciones específicas para momentos históricos distintos en las que Mier se ocupa de los dilemas de cada circunstancia. De ser esto último, en el proceso de selección y adaptación de tesis, argumentos y conceptos, ¿qué tanto se vio limitado Mier por lo que se podía decir, lo que colectivamente se podía escuchar, pensar, admitir y apoyar? No sobra recordar que fueron escritos en una coyuntura de cambio acelerado, de revolución liberal y de independencias dentro de la monarquía española.

En nuestra indagación ponemos énfasis en el uso de las ideas extranjeras o "ideas fuera de lugar", por su origen y contexto. Los hispanoamericanos estaban asimilando las experiencias de dos convulsiones políticas que ampliaron su horizonte de posibilidades y condensaron ideas que aspiraban a tener un carácter universal. Nos referimos a la revolución francesa y, antes, a la independencia de Estados Unidos. Las soluciones que propusieron para la crisis de la monarquía hispana no fueron improvisadas ocurrencias, ni respuestas derivadas de tradiciones intelectuales nativas. Por ello ingresamos al terreno de la historia de los lenguajes políticos. Desde esta perspectiva los discursos son pensados como respuestas de los actores para acometer los principales dilemas que enfrentaba su colectividad ante impredecibles circunstancias. ¿ ¿De qué herramientas conceptuales, socialmente transmitidas, se valió Mier?, ¿de qué manera su pensamiento organizó la experiencia próxima y el pasado más lejano para ofrecer un futuro prometedor?

2 Historia que se ocupa de los discursos entendidos como actos de habla en los que se intersecan redes significtivas. Análisis de contenidos explícitos y dimensión pragmática del lenguaje. Contextualización resume el paradigma. PALTI, "De la historia de las 'ideas"”, pp. 63-82. Darnton, El beso de Lamourette, pp. 203-235. 
Aun cuando es inevitable considerar la procedencia doctrinal de algunas ideas, concepciones y tradiciones contenidas en los dos escritos, buscamos comprender cómo terminó Mier escribiendo acerca de república para la Nueva España independizada; cómo hizo que irrumpiera la palabra e intentó hacerla admisible, cómo decirla para lograr que la comunidad de letrados se adhiriera al diagnóstico elaborado, tanto como a propuestas y objetivos políticos. En otros términos, más que encasillamiento doctrinario, interesa analizar en qué aspectos Mier alteró su discurso en el lapso señalado, advertir qué desplazamientos en categorías y conceptos políticos ocurrieron, qué ambigüedades conceptuales observamos, cómo y sobre qué sustrato conceptual se situaron las ideas "fuera de lugar" y, sobre todo, rescatar los contextos de enunciación de estos discursos para entender lo que propuso el autor. ${ }^{3}$ Intentaremos explicar por qué en ambos escritos continuó siendo pertinente el panfleto de Thomas Paine. Una perspectiva semejante incluye indagaciones sobre el significado que adquirieron conceptos políticos clave y entramados de conceptos; también supone resaltar modificaciones en conceptos políticos básicos, que lograron contener, de manera acabada o no, concepciones de la vida en común dentro del cuerpo político y premisas políticas del orden existente, experiencias y promesas.

\section{ACERCA DE SERVANDO TERESA DE MIER: TEMAS, FILIACIONES, CARACTERIZACIONES}

El polémico Servando Teresa de Mier fue un pensador y político novohispano que contribuyó a llevar más lejos la independencia de Nueva España de la mera separación de la monarquía española. Oriundo de Monterrey (1765-1827), desarrolló su vida pública lejos del núcleo familiar, aun cuando no perdió su amparo.

${ }^{3}$ Palti, La invención de una legitimidad, pp. 34-44. 
Su padre, funcionario real de aquella zona de frontera, lo envió al Colegio Porta Coeli, en la Ciudad de México. Después de ser confirmado sacerdote (1787), ingresó a la Real y Pontificia Universidad de México, doctorándose en Sagrada Teología. Sus tíos, Cosme de Mier y Trespalacios y Juan de Mier, ${ }^{4}$ apoyaron su trayecto aun después de ser inhabilitado por la prédica del sermón sobre la Virgen de Guadalupe que lo llevó al destierro en Las Caldas (1795). A partir de su forzada residencia en la Península, su criollismo encontró cauce político y amplió horizontes en los avatares que padeció la monarquía española y en las conexiones intelectuales que entabló dentro de una vida de escapes y reaprensiones. ${ }^{5}$

De acuerdo con un agudo historiador, pionero en el estudio complejo de la ruptura del mundo hispanoamericano con la corona española, fue desde las filas insurgentes - en las que ubicamos a Mier como simpatizante- desde donde se definió la entidad política que aspiraba a la independencia, abandonando los referentes del original proyecto corporativo, inspirado en el tradicionalismo hispánico y el escolasticismo. Además se adoptaron las tesis de soberanía nacional y constitucionalismo moderno fuera de la experiencia hispánica; ofrecieron la salida republicana para fundar la nueva entidad y conservarla independiente. ${ }^{6}$ Su camino buscaba acabar con un gobierno que sistemáticamente negó derechos a los reinos americanos en plena crisis, entre 1808 y 1814,7 y que dio motivo a una larga y sangrienta guerra civil, por lo que lo llamaron despótico.

Es prácticamente unánime la opinión de los historiadores acerca de la muy temprana decisión de Mier de buscar la

${ }^{4}$ El primero fue rector de la Universidad de Valladolid, alcalde del crimen en la Real Audiencia de México y protector fiscal de Indias, y el segundo fue canónigo de las catedrales de Guadalajara y México.

${ }^{5}$ Domínguez, La vida de fray Servando, pp. 55-102.

${ }^{6}$ Hamnett, "Process and Pattern", pp. 296-297 y 301-305.

7 F.-X. Guerra, "Lógica y ritmos", p. 26. 
independencia absoluta de América; igualmente se le destaca por ser un decidido propagandista de la república a partir de los años veinte del siglo xIx. La conversión republicana de Mier se explica como un quiebre en su referente doctrinario - el constitucionalismo histórico,$-{ }^{8}$ o por el impacto al llegar a Filadelfia y conocer los espectaculares progresos de la república estadounidense, o por influencia de amistades. Semejante mudanza en la oferta de soluciones a la situación de Nueva España ha sido evaluada como endeble y superficial. ${ }^{9}$

Los trabajos de Estrada Michel y Diego Fernández ofrecen pistas para poner en duda algunas afirmaciones arriba expuestas. Nos resultaron de interés sus reflexiones sobre el tipo de adhesión que Mier tenía al constitucionalismo histórico. A nuestro juicio, ambos historiadores aportan elementos para establecer que Mier abandonó dicha doctrina constitucional como argumento político independentista antes de la década de 1820.

${ }^{8}$ Aludimos al constitucionalismo que cambió el orden plural de los Habsburgo, basado en el pactismo neoescolástico y el organicismo. Fue suplantado por otro que aspiraba a ser unitario y centralista, asociado a la sistematización de la "Ley fundamental" y el orden corporativo contenido en la "Constitución". Los ilustrados buscaron "leyes perpetuas" del viejo orden, remontándose a la Hispania gótica y los reinos medievales, desempolvando antiguos códigos: Código legal del Principado de Asturias, Fuero de Jueces, Fuero Viejo de Castilla, las cartas-pueblas, Fuero de Leyes, las Partidas y la Nueva Recopilación de 1567. Jovellanos creía que la pluralidad de leyes, contextualizadas según épocas y principios, daría coherencia y uniformidad a los preceptos, marcaría líneas de evolución y rasgos invariables para configurar un solo pueblo con las mismas leyes. Así, los jurisconsultos aprenderían de la historia a conocer a los hombres y a gobernarlos según el dictamen de la razón y las leyes. Las Cortes reuniría a la nación - como originalmente unieron a las partes de la monarquía - y la voluntad general se expresaría para el arreglo del bien general, conservar la paz interior, extirpando los abusos. Jovellanos, “Discurso", pp. 7-24. Coronas GonzÁLez, "Leyes fundamentales”, pp. 41-48.

9 Rodríguez O., "Introducción”, p. 19. O’Gorman, "Prólogo”, Servando Teresa de Mier, p. xviii. Beltrán Goren, "Servando Teresa de Mier”, pp. 7072. Ávila, "Servando Teresa de Mier”, vol. iII, pp. 19-20. Myers, "El letrado patriota”, vol. I, p. 133. 
Estrada Michel nos recuerda que hacia 1823, indiscutiblemente Mier ya no sostenía ninguna idea de una constitución histórica como soporte de alguna propuesta. No niega que, siguiendo la tendencia predominante, en escritos anteriores a ese año, el padre reivindicaba la existencia de una constitución para los reinos de América en la que se les reconocía independientes y vinculados únicamente al rey. ${ }^{10}$ Aquella Carta Magna era la garantía de las libertades de los americanos; pero, y esto lo subrayamos, el autor sostiene que Mier siempre consideró que la monarquía fue la responsable de la desgraciada suerte de Nueva España, pues aquella constitución había nacido muerta. ${ }^{11}$

Unos años antes, Diego Fernández ya había llamado nuestra atención acerca de ese determinante diagnóstico formulado por Mier: la muerte de la constitución de Nueva España desde su nacimiento. Tal evaluación se apoyaba en afirmaciones de Mier acerca de la historia novohispana e hispanoamericana que justificaban el malestar, la insurgencia y la aspiración de independencia absoluta por la que se luchaba en distintos espacios de América hispánica. A partir del decálogo que condensa el pensamiento político de Mier en su Historia, ${ }^{12}$ el autor destaca las tesis del pacto celebrado entre el rey de Castilla y los habitantes del reino (indios, criollos, negros libres y castas) y la Carta Magna. Igualmente recupera las afirmaciones de violencia e inobservancia de

${ }^{10}$ Es la interpretación de Mier del constitucionalismo histórico para Nueva España. Las disposiciones reales de los siglos XVI y XviI otorgaron derechos perennes a los americanos, por ellas el rey celebró pactos con conquistadores e indios. Las Leyes Nuevas de 1542, el Código de Indias, las Leyes Remuneratorias y la Recopilación de Leyes de los Reinos de las Indias de 1680 conformaron la Carta Magna que fijó y garantizó derechos. Brading, Orbe indiano, pp. 636-639. Rodríguez O., "From Royal Subject", pp. 22-23.

${ }^{11}$ Estrada Michel, "La teoría constitucional”, pp. 25- 26 y 30.

12 En adelante nos referimos así a Historia de la revolución en Nueva España, antiguamente Anábuac: o verdadero origen y causas de ella con relación de sus progresos hasta el presente año de 1813, y sólo la nombraremos Memoria a la Memoria político-instructiva. 
esa Carta a lo largo de 300 años; también las del carácter oneroso del pacto. Diego Fernández subraya una reflexión crucial de Mier: en el pasado inmediato, las resoluciones de las Cortes extraordinarias rompieron el vínculo pactado entre rey y reinos. Por tanto, Nueva España y América hispánica quedaron libres para conjurar las amenazas contra su independencia y buscar su propio modelo político, constitución y gobierno. Igualmente importante es señalar que la preocupación central de Mier no era sostener una monarquía moderada, sino construir un centro de poder fuerte que le permitiera lograr el respaldo de una potencia aliada. ${ }^{13}$

Considerando esta lectura, los argumentos de Mier, basados en el constitucionalismo histórico, tenían un diáfano sesgo negativo; fueron alegatos traídos a cuento para dibujar una situación que Mier encontró inaceptable. En otros términos, el constitucionalismo histórico español en manos de Mier se tornó un instrumento útil para dar fundamento a la tesis de 300 años de despotismo y tiranía; sirvió para demostrar que la Carta Magna no tuvo vida por los embates que le asestaron las autoridades peninsulares y los abusos de particulares españoles. Ciertamente aparecieron en los escritos de Mier desde 1811 y son abundantes en sus dos obras políticas más importantes: Historia y Memoria político-instructiva. Tan reiteradas son las afirmaciones de ese talante, rescatadas por Diego Fernández, que sugieren lo imposible que era para Mier suspirar por un vínculo de vasallaje que en la práctica resultó perjudicial para los americanos. Él no reclama el exacto cumplimiento y vigencia de aquella Carta; la usó para afirmar el desventajoso pacto que celebraron los americanos. Por ello, es dudoso adscribir a Mier dentro de esa doctrina.

A su vez, Mier se ubica en una tradición distinta de las explicaciones que justificaban la insubsistencia del pacto de

${ }^{13}$ Diego Fernández, “Influencias y evolución”, pp. 3-14 y 35. 
dependencia de América con el rey a consecuencia del despotismo y las flagrantes violaciones a la Carta Magna. No es de él ese discurso es de los insurgentes, quienes consideraron justos su causa y el derecho a rebelarse para acabar con la tiranía; razonamiento basado en el pensamiento vigente de Francisco Suárez y su aceptación del tiranicidio. ${ }^{14} \mathrm{La}$ explicación de la insubsistencia del pacto en Mier no parece tener asidero en el neoescolasticismo de ese autor. Tampoco pensaba que el pacto entre rey y reinos americanos se había anulado por las abdicaciones de los Borbones en 1808 o por la cesión que hicieron de la corona a los Bonaparte, ${ }^{15}$ aun cuando sí entendía ser de justicia la reversión de la soberanía a los pueblos que antes la habían depositado en el legítimo rey, una vez que la cabeza de la monarquía fue forzada a abandonar el trono.

La contundente afirmación de Mier de ruptura del pacto al momento en que las Cortes extraordinarias suplantaron ilegítimamente la Majestad Real estando cautivo su titular tenía tras de sí varios supuestos: la vacancia en el trono primero devolvió a los americanos una libertad natural; por el pacto que antes habían jurado, ellos tenían derecho a resistir toda enajenación y rechazar celebrar un nuevo pacto social que no les conviniera. De acuerdo con Mier, el de las Cortes los colocaba en absoluta dependencia, los degradaba a colonos, imponía una obediencia al arbitrio de la nueva autoridad para que recibieran de su mano la ley. Apoyándose en afirmaciones de Blanco White, ${ }^{16}$ entendía que ese nuevo pacto era más desventajoso que el anterior: todo

${ }^{14}$ Ibarra, “«La justicia de la causa»”, p. 78. Ibarra, “Excluidos pero fieles”, p. 78.

15 Ávila, Ortiz Escamilla y Serrano Ortega, Actores y escenarios, p. 210. ${ }^{16}$ Blanco White veía justificados los reclamos de los americanos. También apoyaba la tesis de reversión de la soberanía a los pueblos en ausencia del rey y consideraba que por las resoluciones de las Cortes extraordinarias los españoles debían celebrar una nueva y voluntaria alianza con los americanos. CLAPS Arenas, "José María Blanco White”, p. 27. 
derecho sería para los amos y los americanos sólo tendrían por recurso apelar como esclavos. En tales condiciones, no podían aceptarlo, acción que era de justicia. ${ }^{17}$

Mier fundamentó en otra doctrina la negativa para admitir la transferencia de la soberanía a las Cortes. Para identificarla, creemos conveniente resaltar que la ruptura del pacto alegada por el exdominico está marcada por un binomio conceptual que fue puntal de la acción insurgente y, más tarde, base de la fórmula política que aparece en la Memoria: independencia y libertad como atributos naturales de la persona moral (que refiere a pueblos, reinos, naciones o estados con capacidad de autogobernarse). La libertad revertida al reino de Nueva España inicialmente por la ausencia del rey adquirió un carácter absoluto por las resoluciones de las Cortes. Esa fue la condición por la que la entidad constituida (Nueva España) recuperaba su independencia original; a la vez, tal libertad era el medio para consolidar la independencia recuperada. Binomio fundamental por su significación coyuntural: el reino, en ejercicio de su libertad, era a quien tocaba decidir cuál debía ser el modelo político que mejor conservara la independencia recuperada. ${ }^{18}$

Un razonamiento con tales rasgos es, como adelantamos, ajeno al constitucionalismo histórico español. Pertenece a la tradición iusnaturalista del derecho de gentes. Este es uno de los derechos que se desprendieron de las variadas corrientes de derecho natural, desarrolladas desde el siglo xvi. Además, se derivó del iusnaturalismo racionalista. Este último compartió con esas diversas corrientes - entre ellas la escolástica española - considerar que las leyes de derecho natural eran inmutables y eternas porque estaban asociadas a la justicia y la equidad. A su vez, coincidieron en juzgar ilegítimas aquellas normas jurídicas

${ }_{17}$ J. Guerra, Historia, t. II, pp. 162-166.

${ }_{18}$ Mismo binomio que aparece en los documentos de los insurgentes entre 1813 y 1814. Tecuanhuey Sandoval y Rivas Granados, "El discurso republicano", p. 39. 
que fueran contrarias al derecho natural. Así, las leyes civiles adoptadas para el gobierno de la comunidad política tenían por contención este último derecho. Pero el iusnaturalismo se diferenció de la escolástica española porque consideró que el derecho civil mudaba obedeciendo razonamientos y acuerdos humanos, sin la intervención de Dios y su vicario. ${ }^{19}$

El derecho de gentes, de filiación iusnaturalista, ${ }^{20}$ de manera similar afirmaba el goce de derechos irrenunciables de personas morales (naciones o pueblos). Tales derechos, por su origen natural, eran límites infranqueables al celebrar compromisos y acuerdos de asociación entre diferentes personas morales. Las coaliciones que reunían personas morales eran voluntarias y se deducían de la libertad natural de cada una, de los intereses de su salud común, de la correspondencia mutua y se establecían con deberes recíprocos. El objetivo fundamental era vivir en paz; cuando ello no ocurría, se cancelaban. Las coaliciones no funcionaban orgánicamente porque no eran individuos físicos. Por ello, la autoridad del príncipe estaba limitada por leyes fundamentales, acordadas entre las partes. En una coalición, los asociados tampoco se reconocían como reinos patrimoniales. Cada nación, pueblo o Estado se mantenía soberano e independiente de los demás. La salud de la nación o del pueblo era suprema ley natural que era observada obligatoriamente. ${ }^{21}$

Ese derecho estableció tres circunstancias por las que los súbditos no estaban obligados a la obediencia: si la sujeción entre personas morales con desigual fuerza carecía de pacto; si los pactos de protección o de sumisión no eran acordados en condiciones de libertad e independencia, y si el príncipe transgredía

19 Chiaramonte, Nación y Estado, pp. 138-147.

20 Utilizamos la obra que fue más conocida entre los americanos y que el caraqueño Francisco Miranda citó en uno de sus escritos para mostrar que el derecho de conquista era contrario al derecho de gentes. SAINT Lu y BÉNASSY-BERLING (coords.), Historia de la Revolución, p. lxv.

${ }^{21}$ VATTEL, El derecho de gentes, t. I, pp. viii, xv, xx, xxii, xxv, 72-74 y 78. 
el pacto. Además, la desobediencia se atenía a una regla racional: sólo rebelarse cuando era menos gravoso ponerse en guerra civil que sufrir los males del gobierno. Entonces, en el derecho de gentes la obediencia no podía ser ciega. Finalmente, los pactos entre personas morales quedaban sin efecto en las siguientes eventualidades: cuando alguno de los contratantes faltaba a sus obligaciones, cuando se debilita hasta no poder proveer la protección prometida, o al momento en que la potencia superior se arrogaba más derechos que los otorgados por el tratado de protección o de sumisión inicial. Era entonces cuando la parte subordinada recobraba sus derechos, independencia y libertad y podía celebrar un nuevo pacto con otras entidades, si así quería. ${ }^{22}$

A nuestro juicio estas son las tesis en que se fundamenta Mier para justificar la recuperación de la libertad y la independencia natural, la ruptura del vínculo de vasallaje y la defensa de la independencia absoluta de Nueva España. Ideas que Mier sostuvo en 1811 y 1812, tras la independencia y Constitución confederal de Venezuela del $1^{\circ}$ de julio de 1811 , cuando perdió las esperanzas sobre la igualdad jurídica para América en la experiencia constitucional. ${ }^{23}$ En las Cartas de un americano a un español que Mier escribió apasionadamente polemizando con Blanco White se invocaban ya los derechos irrenunciables de las personas morales. Como se recordará, el editor de El Español favorecía una monarquía moderada para la española en crisis y promovía una política de conciliación con los americanos; juzgaba que los hispanoamericanos carecían de suficiente experiencia política

${ }^{22}$ VATtel, El derecho de gentes, t. I, pp. 257-263.

${ }^{23}$ Después de 1813 los insurgentes hicieron énfasis en dos derechos irrenunciables desde el derecho de gentes: la igualdad natural de los seres humanos y la negación a ser una nación patrimonio de una persona o familia. ÁvILA, ORTIZ Escamilla y Serrano Ortega, Actores y escenarios, p. 258. Igualmente véase la apelación de Carlos María de Bustamante al derecho de gentes al redactar el discurso de apertura del Congreso de Chilpancingo. IBARRA, El cabildo de Antequera, pp. 173-177. 
para consolidar su independencia y la república. En el marco de un debate fraterno, el clérigo español daba la razón a los opositores americanos e incluso entendía sus sentimientos; por ello abrió las páginas del periódico para difundir sus opiniones y denunciar la política inflexible de la Regencia y de las Cortes. ${ }^{24}$ Los agravios eran históricos y profundos, de ahí que Blanco White reconociera finalmente la inevitabilidad de la separación.

Lo que llama nuestra atención es que Mier, quien defendió a los independentistas republicanos caraqueños, no asociara en la Historia el planteamiento de independencia absoluta con una propuesta de reorganización republicana de la comunidad política para el reino novohispano. ¿Por qué motivos no enunció esa salida? Hasta ahora no hemos recogido de su Historia argumento alguno que pusiera en entredicho a la monarquía como forma de gobierno conveniente para conservar la independencia absolutamente recuperada. No obstante, y avanzando en la perspectiva que propusimos, hemos de poner cuidado en otra cuestión relacionada: las referencias al republicano Thomas Paine y la transcripción de ideas, a veces literal, de tesis y párrafos del panfleto Common Sense en los escritos de Mier mencionados.

No hay duda entre los historiadores de que Paine es una de las influencias reconocibles en la Memoria de 1821. Hasta donde hemos verificado, sólo dos autores la han detectado en los escritos que nos interesan. El primero fue David Brading; años más tarde lo hizo Domínguez. ${ }^{25}$ En su análisis el historiador del patriotismo criollo afirma que Mier recibió la influencia republicana en Europa de Henri Gregoire, es decir, entre 1802 y 1815, adhesión que atendió a razones históricas y geográficas, sin razón universal o razonamiento abstracto de política. ${ }^{26} \mathrm{El}$

${ }^{24}$ Claps Arenas, “José María Blanco White”, pp. 5-40. BreÑa, El primer liberalismo, pp. 311-318.

25 Domínguez, La vida de fray Servando, p. 402. Brading, Orbe indiano, pp. 636, 639-640.

${ }^{26}$ Brading, Orbe indiano, pp. 642 y 647. 
contacto con la definida personalidad republicana y galicana de Gregoire lo menos que sugiere en el terreno político es que antes de estallar la crisis española contribuyó a ampliar el horizonte de soluciones a ofrecer al estallar los movimientos independentistas. El derecho de gentes era buena doctrina para apelar por la independencia y la libertad, pero no para pensar una reorganización del gobierno en cada pueblo o nación.

¿Nos puede arrojar luz el estudio de la presencia de Paine en los escritos de Mier para entender por qué se hizo republicano? ¿El panfletista inglés, así considerado por largo tiempo, tenía un pensamiento sistematizado sobre el republicanismo? ¿Este está expuesto en Common Sense? ¿Qué segmentos del pensamiento de Paine aparecen en los mencionados escritos de Mier?

\section{THOMAS PAINE: ¿PANFLETISTA Y PENSADOR POLÍTICO?}

En el frío de Nueva Inglaterra, hacia 1776, un delgado y barato panfleto era vendido al grito de "Common Sense for eigtheen pence". ${ }^{27} \mathrm{~A}$ la vez que se agotaban las impresiones del escrito, rápidamente se propagaban las ideas incendiarias de su autor dando cuenta de un cambio radical en la visión del mundo de fines del siglo XviII. Había ocurrido un súbito quiebre: en las Trece Colonias la noción de obediencia al rey se reemplazó por otra, en que el pueblo fue a la vez gobernado y gobernante. ${ }^{28} \mathrm{El}$ argumento de Paine de ser de sentido común que una isla no pudiera gobernar todo un continente distante y sin supervisión de los ciudadanos fue acogido por los delegados que se reunieron en el Congreso de Filadelfia. Esa idea no fue la única que suscribieron; también decidieron quedar libres de la "histórica e intrínseca corrupción de las monarquías". ${ }^{29}$

\footnotetext{
27 Rosenfeld, Common Sense, p. 137.

28 Rosenfeld, Common Sense, p. 137.

29 Ellis, Founding Brothers, p. 3.
} 
El lugar de Thomas Paine en la literatura académica ha cambiado. Primero fue considerado un escritor menor, indiscutiblemente genio del panfleto pero sin estatura de gran pensador. Harry Hayden Clark, por ejemplo, resalta su presencia por el éxito editorial de sus obras, pero explica que contaba con una amplia red de impresores que reeditaron sus textos a bajos costos. Reconoce que la popularidad se debía al estilo que lo convirtió en maestro del arte de la persuasión y de la prosa controversial. Con la información que obtenía de participar en círculos racionalistas y espacios de efervescencia intelectual y política, suplía su falta de escolaridad. A partir de ahí escribía de forma simple, aguda y clara. Tomado el pulso de la sensibilidad social lanzaba frases atrevidas para afirmar convicciones plenas de fe en el futuro y ciegas a los elementos inconscientes e históricos de la acción humana. Apelaba a los sentimientos manejando la connotación, antítesis, balance y cadencia en la composición, para producir placer durante la lectura. Asegura que no creó opinión popular; ésta ya existía. La organización del argumento conseguía asombrar, hacer pensar, evitar el escepticismo y arrancar compromisos. ${ }^{30}$

Recientemente el tipo de documento, la obra global y el autor han sido revalorados. El panfleto es hoy un escrito importante para analizar la historia de la opinión pública, el pensamiento informal y la difusión de ideologías. Por medio de él se estudian prácticas sociales modernas, el imaginario sociopolítico, la configuración del espacio público. Es un género de propaganda, ocupado de temas de actualidad, carente de referencias exactas y de profundidad; generalmente amalgama ideas, momentos históricos, y por el objetivo de convencer al público acerca de una opinión, sus autores combinan estilos cómico serios. ${ }^{31}$ Pero no todos los panfletos asumen rasgos propios de textos simples;

${ }^{30}$ H. Clark, “Thomas Paine's Theories”, pp. 307-321.

${ }^{31}$ Rodríguez Cascante, “Tierno Galván”, pp. 15 y 16. 
los que son escritos complejos cumplen con varias condiciones: seriedad del tema que tratan, objetivo, elementos retóricos, usos políticos y repercusiones polémicas. ${ }^{32}$ La dimensión dialógica es determinante: ahí el panfletista actúa sobre un horizonte de expectativas del público lector. ${ }^{33}$ De manera que el contexto de este tipo de escritos influye en su contenido y forma.

Common Sense forma parte del subconjunto de escritos complejos; rasgos que, insistimos, no sólo derivan de las habilidades natas o cultivadas del autor. Paine creció en un medio de muy larga tradición panfletaria de corte político. De acuerdo con lo que sabemos de manera indirecta, durante la temprana edad moderna británica (1630-1800) el panfleto fue un medio para opinar, un espacio de pensamiento y lectura reflexiva. Tuvo gran impacto en la vida institucional británica e incidió profundamente en la cultura política inglesa, pues contribuyó a fundar comunidades de influencia moral y política. Éstas constituyeron la esfera pública que animó la opinión y la acción popular en momentos clave: la revolución inglesa, la Restauración y la crisis de 1678. Adicionalmente, este tipo de escritos atrajo nuevas voces al debate público - como mujeres, cuáqueros y críticos de todo tipo-, siempre con resonancias en el Parlamento. Su presencia y circulación favoreció la metamorfosis del impreso, transformándolo en el medio del que dependió la vida pública británica, desde un siglo antes de la aparición de los privilegiados espacios de la opinión pública del siglo xviII europeo: los cafés o los salones literarios. ${ }^{34}$

Es posible resaltar la importancia de esta tradición si consideramos el papel que desempeñaron los panfletos en otras latitudes y tiempos. Estos escritos también contribuyeron al surgimiento de la opinión pública española, la crítica política y

32 ClegG, "Joad Raymond, Pamphlets", p. 609.

${ }^{33}$ Rodríguez Cascante, "Tierno Galván”, p. 16.

${ }^{34}$ Clegg, "Joad Raymond, Pamphlets”, pp. 608-609. 
la promoción de soluciones de cambio. Pero el estilo predominante los diferenció radicalmente del inglés. En la eclosión de esa folletería que ocurrió desde la última década del siglo xviII, hasta las deliberaciones de las Cortes en Cádiz, se deja ver que fue un medio frecuente para expresar lo amado y lo odiado, de habla directa y defensa visceral, escritos con deliberado aire efímero. Aun cuando contuvieron una implícita reivindicación de la libertad de espíritu, alentaron la asidua discusión callejera, y su dimensión subversiva la adquirieron por la diatriba, mas no por la fuerza de las ideas. ${ }^{35}$

En Francia el panfleto fue más versátil y diverso en funciones o rasgos al avanzar la segunda mitad del siglo xviII. Apareció en 1653 confundido con el libelo; después tuvo momentos en que contribuyó seriamente al debate y a la maduración de la opinión pública; destaca la relevancia que adquirió tres décadas antes del estallido de la Revolución. Sus autores formaban parte de la avalancha de jóvenes escritores fracasados que infructuosamente buscaron incorporarse al movimiento ilustrado de Le Monde..$^{36}$ Como parte de la canaille de la littérature, los panfletistas proyectaban un "mundo hobbesiano" plagando los escritos de sordidez, imprecaciones y diatribas contra la jerarquizada República de las Letras y el orden social. Puesto que a sus ojos imperaba un estado general de degeneración que comenzaba por la monarquía, la denuncia de la corrupción concitaba el cotilleo de café. Había ánimo para derrocar a los líderes del régimen, pero el estilo no formalizó un programa político. ${ }^{37}$

Los escritores de memorias judiciales fueron otro tipo de panfletista en Francia. Entre 1770 y 1780, en general abogados con seudónimo, fueron más incisivos en el surgimiento de la opinión pública. La difusión impresa de causas particulares

${ }^{35}$ González Troyano, "Los libelos ilustrados”, pp. 367-369 y 373.

${ }^{36}$ Chartier, "El hombre de letras", pp. 158-162 y 172.

${ }^{37}$ Darnton, Edición y subversión, pp. 34-55. 
contribuyó a hacer de los asuntos jurídicos, temas públicos de debate general y moralización. Ahí quedaron exhibidas la iniquidad judicial y la desigualdad social, a la vez que se fue sedimentando la defensa del derecho natural y las teorías del contrato social. ${ }^{38}$ Durante la revolución francesa, el panfleto político fue el medio más utilizado entre los partidarios del rey y los revolucionarios. Para los primeros fue medio de denuncia y condena de los revolucionarios; para los segundos fue instrumento para orientar a la opinión, aprovechando su especificidad temática, mayor libertad de circular y comunicabilidad. ${ }^{39}$

En resumen, los contextos de producción (circunstancias y públicos) evidentemente influyeron en la complejidad y alcance político de los panfletos. Common Sense tuvo una exitosa recepción, entre otras razones, porque se dirigió a una audiencia nutrida por la tradición británica señalada. ${ }^{40}$ Una tradición en la que los panfletistas raramente escribieron "ciegos de odio" o con "temor pánico". Ellos tenían intenciones comunicativas efectivas. ${ }^{41}$ Pero el éxito de Common Sense de su tiempo disminuyó ante los estudiosos de la historia contemporáneos en razón de las evoluciones de la historia política estadounidense y de la atracción que tuvo el pensamiento de otros miembros del círculo de Padres Fundadores que resultó más explicativo para ciertas preguntas. No descartamos que el tema que anuncia ser tratado en el título del panfleto, el sentido común, también lo alejara del escritorio.

Como es de advertirse, Thomas Paine promete ocuparse de un asunto de la vida en comunidad contrario, aparentemente, a la época de la razón en tanto que es un sentido hecho de percepciones. En efecto, el sentido común nos traslada a la vida cotidiana,

\footnotetext{
38 Estos documentos se diferencian de los escritos difamatorios por su tono y contenido. MAzA, “Le Tribunal de la nation”, pp. 73-79.

39 Chisick, "Pamphlets and Journalism”, pp. 626-628, 634 y 639.

40 Elliot, Imperios del mundo, pp. 482-483.

41 Baylin, The Ideological Origins, cap. I.
} 
a las experiencias ordinarias, a las observaciones sancionadas por la práctica; un sentido gestado por conocimientos provenientes del pensamiento ingenuo y de un modo de razonar estimativo y apreciativo. Distanciado de la lógica, por mucho tiempo se consideró que lo propio de la ciencia era romper con él y trastornarlo en su totalidad. ${ }^{42}$ Sin embargo, hoy el sentido común es valorado pues permite entender comportamientos colectivos, en tanto que es un recurso por el que los individuos comprenden su mundo, resuelven desafíos y enfrentan problemas. ${ }^{43}$

En los terrenos de la teoría política, el sentido común ha tenido generalmente un mejor lugar de consideración. Se le entiende como conjunto de referencias de adaptación al mundo y coordinación de unos con otros. Él configura una percepción colectiva del mundo al que se pertenece, constituye la realidad común y el sentido de esa realidad. A través de él se juzga, discurre y actúa; permite a los individuos moverse y comunicar sobre el común. ${ }^{44}$ El sentido común es, entonces, condición de comunicabilidad y sociabilidad; también de mutabilidad debido a que por medio de él, los miembros de la comunidad política meditan sobre lo justo y lo bueno, dan cabida a la duda y al disenso. ${ }^{45}$ No es extraño entonces que Sophie Rosenfeld, ocupada del asunto, concluya que Paine apela al sentido común que entiende y extrae del bon sens del siglo XviII elaborado por Montesquieu; es decir, sentido que establece verdades básicas conceptuales, conocidas y aceptadas por todos. ${ }^{46}$

Paine sabía que el título dado a su escrito era de gran calado; el panfleto tuvo tal importancia en sus propias reflexiones que en obras posteriores profundizó ideas esbozadas ahí. ${ }^{47}$ Sintió

\footnotetext{
${ }^{42}$ Moscovici y Miles, “De la ciencia al sentido común”, pp. 679-682.

43 Sото, "Sentido común”, pp. 63-66.

44 Pereila Martos, “La pérdida del Sentido Común” pp. 427-434.

45 Hernández Prado, “Alcances y limitaciones”, pp. 144-146.

46 Rosenfeld, Common Sense, p. 91.

47 Paine confesó que el objetivo y principios de su segunda obra, The Rights of
} 
orgullo de escribirlo y adoptó por pseudónimo el nombre del exitoso panfleto para posteriores escritos, en un gesto de valoración de la fuerza movilizadora que tuvo. ${ }^{48}$ Common Sense no fue el primer panfleto político que Paine escribió. En 1772 y en su país natal publicó "The Case of the Officers of Excise" con el que inició una meteórica trayectoria como publicista. Las repercusiones políticas de su escritura sorprendieron a los círculos y clubes políticos londinenses. Logró ser discutida en el Parlamento inglés la denuncia que Paine formuló de la precaria condición social de los recaudadores portuarios del imperio, en la que volcó su experiencia personal. Al exponer su talento, los círculos de escritores lo atrajeron, apreciando su mente aguda y elevándolo al rango de panfletista político. ${ }^{49}$

A partir de entonces, Paine apareció como la personificación de la escritura rebelde. En razón de los cargos políticos que tuvo en la administración municipal y parroquial de Lewes, comprendía el funcionamiento del Parlamento inglés, el sistema de representación desigual que lo configuraba y la marcha del aparato gubernamental. ${ }^{50}$ Esa experiencia lo convenció de la corrupción del gobierno inglés, cuya crítica lo ubicó en la cúspide del debate anticolonial. ${ }^{51}$ Su ingreso a los círculos literarios de la capital del imperio en 1772 lo afamaron como hombre de

\footnotetext{
Man, cuya popularidad y polémica superó a Common Sense, eran los mismos que los defendidos en el panfleto que nos ocupa. Señaló que la única diferencia radicaba en considerar los públicos y las circunstancias locales: Common Sense fue escrito para América y los americanos, The Rights of Man para Inglaterra y los británicos. Paine, "Thomas Paine to the Citizens", p. 382.

${ }^{48}$ Con ello abandonó la costumbre de autodenominarse "cosechador de pensamientos" o "Farmer of thoughts" que usó desde 1778. Paine, "To the Authors", pp. 4-5. PaIne, "Letter to Henry Laurens", p. 211.

${ }^{49}$ Foner (ed.), Thomas Paine: Collected Writings, p. 15.

${ }^{50}$ Entre 1769 y 1772 fue miembro de la junta parroquial, presidente de la municipalidad y auditor de cuentas del condado. Foner (ed.), Thomas Paine: Collected Writings, p. 4. Vickers, My Pen and my Soul, pp. 105-106.

${ }^{51}$ Foner, Tom Paine, pp. 1-18. Vickers, My Pen and my Soul, p. 54. FruchtMan, The Political Philosophy, pp. 16, 19-20.
} 
horizonte intelectual arraigado en las Luces. Estaba interesado y versado en las innovaciones técnicas tanto como en la lectura de tratados políticos. Fue asiduo a los fondos de la Royal Society donde repercutía la revolución científica de su tiempo. ${ }^{52}$ Muy activa participación tuvo en el White Hart Evening Club, asociación voluntaria en la que se discutían temas públicos locales, nacionales e internacionales, desarrollándose como gran polemista. ${ }^{53}$ Benjamín Franklin lo incorporó al Club of Honest Whigs. ${ }^{54}$ El perfil bajo que adoptó ahí probablemente favoreció el que profundizara en el conocimiento de los temas que se debatían: la corrupción de la sociedad inglesa, la virtud individual y gubernamental, así como la igualdad.

Dos años más tarde Paine llegó a Filadelfia alentado por Franklin, incorporándose a la revista Pennsylvania Magazine de Robert Aitken. ${ }^{55}$ Dedicó su pluma a preocupaciones inéditas de la sociedad estadounidense, temas de la escritura rebelde: la situación de mujeres, niños, el mundo del trabajo, los esclavos, enfermos mentales, maltrato animal. ${ }^{6}$ Poco después fue inevitable escribir sobre temas políticos, aun cuando lo hizo de manera indirecta. Metafóricamente denunció la opresión británica, su corrupción e interferencia en los asuntos de las colonias. ${ }^{57}$ Escritos tempranos constituyeron anticipos de las opiniones de Paine sobre la situación de las Trece Colonias y su relación con Gran

${ }^{52}$ Hombre ilustrado a pesar de carecer de estudios superiores. Su fama lo hizo merecedor del grado de Master of Arts por la Universidad de Pensilvania en 1780. Claeys, Thomas Paine, pp. 21-22.

${ }^{53}$ H. Clark, "Thomas Paine’s Theories", p. 311.

${ }^{54}$ Vickers, My Pen and my Soul, Apéndice.

${ }_{55}$ Nelson, Thomas Paine, cap. 3. Fraire, Pensadores norteamericanos, p. 71.

${ }^{56}$ Pisarello, "Vindicación de Thomas Paine", p. 235. Nelson, Thomas Paine, cap. 3.

${ }^{57}$ En dos fábulas, "Cupid and Hymen" y "A Dream Interpreted", representó la lucha de América (Cupid) por su independencia. Paine, "Cupid and Hymen”, pp. 36-39. Fruchtman, The Political Philosophy, p. 61. Paine, "A Dream Interpreted", pp. 48-50. 
Bretaña. En Common Sense vuelve más extensamente a ellas para ofrecer soluciones. Escribió en un momento de máxima tensión en la relación con la metrópoli que provocó protestas contra el monopolio del té, incremento de impuestos, restricciones en la compra de tierras para las colonias inglesas y una reforzada presencia imperial que clausuró el puerto de Boston, no evitó la masacre y canceló libertades en Massachusetts. ${ }^{58}$

En ese contexto social y político apareció el panfleto que apostaba a definiciones radicales. Animado por su voluntarismo ilustrado, ${ }^{59}$ Paine advirtió que estaba frente a una inédita oportunidad de cambio. A partir de 1776 se convirtió en coautor del pensamiento republicano estadounidense. Al lado de Franklin combatió los principios jerárquicos y hereditarios del antiguo régimen. ${ }^{60}$ Junto con James Madison, a pesar de abismales diferencias, pensó la república como única alternativa a la monarquía, que a sus ojos era sinónimo de esclavitud y tiranía. ${ }^{61}$ Pero desarrolló ideas propias. Paine fue el republicano demócrata más influyente de su tiempo. ${ }^{62}$

Dicha definición fue más clara al triunfar la independencia estadounidense y firmar el Tratado de París. Desde 1783 retomó exitosamente la escritura de sus más importantes ensayos y se interesó en alentar a los británicos para obtener su propia república. Para entonces, Inglaterra vivía en agitación política por la presión autonomista en Irlanda, el surgimiento de asociaciones radicales y los motines de Gordon que se produjeron simultáneamente al despliegue de la revolución industrial. ${ }^{63}$ Radicado en su patria natal escribió y publicó The rigths of man, que originó

\footnotetext{
${ }^{58}$ SOLÉ, Las revoluciones, p. 27.

${ }^{59}$ Hobsbawm, Uncommon People, cap. 1.

${ }^{60}$ Kramnick, "Thomas Paine”, p. 135.

${ }^{61}$ Kalyvas y Katznelson, Liberal Beginnings, IV parte. Hobsbawm, Uncommon People, I parte.

${ }^{62}$ Claeys, Thomas Paine, p. 6.

${ }^{63}$ Bergeron, Furet y Koselleck, La época de las revoluciones, pp. 22-24.
} 
la condena inglesa como escritor de libelos, por lo que en 1791 tuvo que huir hacia París, en donde permaneció hasta 1802.

Gracias a la promoción de la república que hizo en la Convención Francesa, tenemos una síntesis de la tesis central sobre el republicanismo que defendió. Por república, escribió Paine, "simplemente entiendo al gobierno por representación - un gobierno fundado en los principios de la Declaración de Derechos". ${ }^{64}$ En otro escrito explicó que la república era el imperio de leyes fundadas en dos grandes principios: representación electiva que nacionaliza la perspectiva de los representantes y derechos humanos. Era un modo de gobierno adecuado para un amplio territorio; la elección y representación ofrecía seguridad a los ciudadanos y protección de sus derechos; facilitaba la comunicación entre representados y representantes; respetaba el derecho, la libertad y la voluntad de los ciudadanos para que decidieran regularmente el destino colectivo. En pocas palabras, como republicano, Paine no conocía otra majestad que la del pueblo, ni otro gobierno que el del cuerpo representativo, ni otra soberanía que la de las leyes. ${ }^{65}$

Paine además defendía la igualdad jurídica, la renovación de mandato y la supremacía de la ley, tanto como la del parlamento sobre el Ejecutivo. No creía en el derecho consuetudinario porque pensaba que la constitución emanaba del racionalismo y de la representación política; la legitimidad de la constitución quedaba entones afincada en la práctica democrática.${ }^{66} \mathrm{El} \mathrm{repu-}$ blicanismo así concebido era la alternativa a la monarquía, la aristocracia y el gobierno mixto. ${ }^{67}$ De ahí su tono liberal. Pensó al gobierno representativo como centro neutral capaz de lidiar, comandar y congregar las partes de la complejidad social, reunir

\footnotetext{
${ }^{64}$ Paine, "Letter to the Abbé Sieyès", pp. 381-382.

${ }^{65}$ Paine, "To the Authors", pp. 4-8.

${ }^{66}$ Pisarello, "Vindicación de Thomas Paine", pp. 235, 243 y 245-246. FoNER, Tom Paine, p. 76.

${ }^{67}$ Claeys, Thomas Paine, pp. 1-6.
} 
los variados intereses de una sociedad que en sí misma era plural. La ciudadanía libre era el otro pilar del modelo republicano de Paine; de ahí que fuera fundamental la protección del igualitarismo, los derechos individuales y la libertad religiosa. Paine también compartió la perspectiva contractualista. La asociación política constitucional estaba mediada por un contrato social en el que los individuos incrementan su poder con la suma del poder de todos y no lo transfieren. ${ }^{68}$

Un orden así pensado se preparaba para alcanzar el progreso equilibrado de una sociedad comercial, que era preocupación central de los contemporáneos, pues intentaban neutralizar el efecto corruptor del mercado. Paine, campeón del antielitismo, no veía contradicción entre el mercado y la república; ambos podían ser compatibles en la medida en que el privilegio fuera excluido, la riqueza redistribuida y colectivamente se velara por la igualdad social. ${ }^{69}$ Lejos estaba de creer que naturalmente la sociedad comercial se autorregulaba. El mecanismo que regulaba la relación entre república y mercado era la virtud republicana que Paine pensó diferente de la virtud de los antiguos, la virtud cívica con su espíritu agonal. Creyó que la sociedad y el gobierno se salvarían de la corrupción por un compromiso que no dependía del diseño de una arquitectura institucional capaz, por sí misma, de mantener el equilibrio interno de poder. ${ }^{70}$ Apostando a las capacidades racionales del hombre común, la virtud republicana en Paine debía ser compartida por los ciudadanos y los que gobiernan y los que representan. Consistía en un compromiso colectivo por lograr el bienestar colectivo. Es aquí donde engarza la vertiente social de su pensamiento.

${ }^{68}$ Kalyvas y Katznelson, Liberal Beginnings, IV parte. También Foner, Tom Paine, p. 87.

${ }^{69}$ Foner, Tom Paine, p. 94.

70 Para el análisis de las propuestas de ese corte decantadas en la tesis de gobierno balanceado véase Pососк, El momento maquiavélico, pp. 627-629. 
Paine mantuvo una preocupación constante por las fuerzas que empujaban a los hombres hacia la pobreza, en contrasentido con los progresos de la economía y la industrialización. Encontró que la pobreza era incompatible con la civilización y la felicidad. ${ }^{71}$ En sus obras Los derechos del hombre y Justicia agraria (Francia, 1797) reflexionó sobre los aspectos de aquel problema: desempleo, incapacidad, miseria y desprotección de los más débiles. Estos temas debían ser atendidos en la república porque incidían en su salud; razón y paz civil estaban implicadas. Había que propiciar el bienestar; la autoridad política debía promover la felicidad pública y el gobierno debía equilibrar por diferentes medios las inequidades; uno de tales medios era el gasto público. El bienestar fue elevado por Paine al rango de derecho natural, renovando la idea de derecho natural a la propiedad, que debiera ser para todos. ${ }^{72}$ La teoría del igualitarismo de Paine quedó enmarcada en la teoría del derecho natural y los derechos sociales fueron considerados imprescriptibles. Era necesario afirmarlos porque el desarrollo de la civilización los había anulado para muchos. ${ }^{73}$ La virtud republicana, entonces, definía la principal función de gobierno: redistribuir la riqueza. ${ }^{74}$

La contribución de Paine al pensamiento político se condensa en la fórmula política republicana y democrática afirmada en la virtud que nacionaliza a los representantes y los compromete, junto con los ciudadanos, a proteger simultáneamente libertades individuales y propiedad con bienestar colectivo. Tal fue

\footnotetext{
71 Hobsbawm, Uncommon People, cap. 1.

72 Ellis, “Radical Lockeanism”, pp. 828-831. Seaman, “Thomas Paine: Ransom”, pp. 122-128. Kalyvas y KATZnelson, Liberal Beginnings, IV parte. Pisarello, "Vindicación de Thomas Paine”, p. 235.

73 Seaman, “Thomas Paine: Ransom”, pp. 33-35.

74 En rechazo a la desmedida acumulación de tierras o de riqueza, Paine diferenciaba entre propiedad adquirida por trabajo, por especulación y por comercio; además establecía que la tierra cultivada adeudaba "una renta de suelo" a la comunidad que era pagada por gravámenes que hacían factible la distribución de la riqueza. Shapiro y CALvert, "Introduction”.
} 
su alternativa a la monarquía para favorecer el desarrollo de la sociedad comercial y, simultáneamente, evitar la corrupción de la sociedad y el gobierno. La suya fue una redefinición radical de la república. Cerró su contribución al pensamiento político, elaborado durante la época de las revoluciones estadounidense y francesa, con la promoción de una revolución de la fe. En The Age of Reason (Francia, 1794 y 1795) hizo la invitación a la completa liberación de los ciudadanos por medio del deísmo, que pensó que era la religión que acercaba más a la razón y a la verdadera esencia de un solo dios. Esa era el ancla que preservaba imperativos morales entre los ciudadanos, ausentes en la época del Terror, contra la que se opuso y por la que sufrió prisión. ${ }^{75}$

No todas las materias de las que se ocupó Paine estuvieron expuestas o contempladas en el panfleto de 1776. Para cuando Mier conoció la obra del afamado panfletista, éste ya había completado la formulación de su pensamiento. No simpatizó con todo. Pero los objetivos e inquietudes de Mier se colmaron en Common Sense.

COMMON SENSE, EL BINOMIO DE INDEPENDENCIA Y REPUBLICANISMO

El periodo de aparición de las obras en que Paine maduró su propuesta republicana corrió entre 1772 y 1797 . Common Sense, de 1776, fue el primer escrito político que originó ese ideal. Su tono, adecuado al momento revolucionario en que apareció, puso fin al debate público que, desde mediados del siglo xviII, había girado en torno a mejorar las condiciones de administración de las Trece Colonias. ${ }^{76} \mathrm{La}$ espectacular venta que tuvo fue síntoma de que vio la luz en el momento de madurez estadounidense; él anunció el advenimiento de la independencia de las

75 Paine, "The Age of Reason", p. 667. Shapiro y Calvert, "Introduction”.

${ }^{76}$ Kramnick, “Thomas Paine”, p. 149. Elliot, Imperios del mundo, p. 482. 
colonias. Fue el tiempo en que se definió la ruta a seguir de los estadounidenses, respondiendo al reto que, quizá involuntariamente, les dibujó el republicano inglés James Harrington, autor de Oceana. Él, en 1656, había imaginado a las colonias británicas en América como bebés que no podían vivir sin nutrirse del pecho metropolitano; faltaba ver, dijo, si cuando maduraran decidían "destetarse". ${ }^{77}$ Common Sense mostró que ya era el tiempo y contribuyó a este último destino.

Una vez que la disociación de caminos se precipitaba, las herramientas intelectuales que viajaron desde la isla facilitaron el pensar opciones que no prosperaron allá o que negociaron con la realidad. Common Sense empujó simultáneamente la independencia de las Trece Colonias y la reformulación de las bases de la organización política. Con ello, Paine logró posicionar el debate colonial en torno al de la república, transformando los términos de la discusión política en ambos lados del Atlántico. ${ }^{78} \mathrm{Al}$ precipitarse la independencia en términos republicanos comenzó a sedimentarse la idea de que el Viejo Mundo simbolizaba el pasado y el Nuevo representaba el futuro. ${ }^{79}$

Las propuestas del panfleto de 1776 al parecer no fueron idea única del inglés recientemente inmigrado. Se atribuye a Benjamin Rush haber animado a Paine a escribirlo. Ellos, que se habían conocido en la imprenta de Aitkin, compartieron intereses y afinidades en algunos asuntos políticos. Uno de ellos fue el de la esclavitud. Rush, cofundador de Pennsylvania Society for Promoting the Abolition of Slavery, se identificó con el tratamiento que Paine dio a ese problema en sus escritos. Otros asuntos los acercaron hasta que juzgaron que había llegado el momento de inclinar la opinión pública a favor de la separación de las colonias. El propósito parecía oportuno;

77 Harrington, “The Commonwealth of Oceana”, p. 44.

78 Foner, Tom Paine, p. 74.

79 Elliot, Imperios del mundo, p. 482. 
había que romper el equilibrio que existía en el debate colonial para cancelar la posible reconciliación de las Trece Colonias con Gran Bretaña, por ambos considerada corrupta. Al concluir su redacción, Paine discutió con Rush la pieza que tituló Plain Truth; luego del intercambio, Paine lo nombró Common Sense. ${ }^{80}$

La escritura y el estilo de Paine en el texto tuvieron las características descritas por Clark, expuestas antes. Por medio de varios recursos literarios, el panfleto apeló a la razón y a las emociones. Sin embargo, Foner subraya con justicia que el poder del escrito se encontraba fundamentalmente en el argumento: hacer ver la razón justa y la necesidad de ejecutarla. Es decir, optar a la vez por independencia y república. Paine fue persuasivo para hacer entender que una era respuesta a la otra. ${ }^{81}$ No escribió en el aire. A las colonias americanas habían llegado reflexiones políticas del siglo xviII inglés que suscitaron evoluciones en la monarquía inglesa, frecuentemente en tensión por el equilibrio inestable que sostenían el mito de la Ancient Constitution, el poder del Parlamento, el carácter representativo de la Cámara de los Comunes, las atribuciones del rey y la sociedad comercial. Estaban acostumbradas al debate del constitucionalismo, el imperio de las leyes acordadas para, en su cumplimiento, preservar la libertad de los hombres, la exclusiva intervención humana en el arreglo constitucional, las derivaciones del antimonarquismo y la amenaza de corrupción.

Entre el abanico de reflexiones que los colonos pudieron conocer destacan las de Thomas Gordon y John Trenchard

${ }^{80}$ El prominente médico Rush suscribió la Declaración de Independencia en 1776. Regresó a América de Escocia en 1769 con ideales republicanos; también creía necesario salvar la virtud americana de la corrupción británica. LAMBERT, “Benjamin Rush”, pp. 443-454. Katcher, “Benjamin Rush's Educational Campaign”, p. 274. Vickers, My Pen and my Soul, p. 55. Nelson, Thomas Paine, cap. 3.

${ }^{81}$ Foner, Tom Paine, pp. 75-76. Kalyvas y Katznelson, Liberal Beginnings, IV parte. 
escritas en Cato's Letters entre 1720-1723..$^{82}$ Movidos por el deseo de impedir la corrupción de Gran Bretaña ellos defendieron la libertad como derecho de toda la humanidad para elegir y obrar por su interés; ${ }^{83}$ sostuvieron que hacer pervivir la libertad requería de cierta igualdad en la distribución de la propiedad, aun cuando no se precisó cómo ejecutarla. ${ }^{84}$ Catón también vio en el comercio una amenaza, puesto que favorecía el dominio de las pasiones en los hombres por sobre los principios; propiciaba el desplazamiento de la virtud cívica a favor del interés personal. Otros problemas fueron igualmente apuntados: la tendencia a la tácita negación del fundamento de la Constitución antigua, la neutralización del instrumento por el que el pueblo británico había conquistado la libertad, The Bill of Rigths y el desequilibrio entre rey, lores y comunes en el ejercicio conjunto de la soberanía. ${ }^{85}$ Catón diagnosticaba un frágil estado entre libertad y corrupción, no obstante, confiaba en que algunos miembros de la aristocracia superarían estos problemas por el desarrollo en ellos de una pasión loable: el interés público. ${ }^{86}$

Además, circularon las tesis de Henry St. John, Vizconde de Bolingbroke. Partidario de la monarquía constitucional, en oposición al gobierno ministerial y al carácter divino de los gobiernos, fue conocido por sus escritos sobre la corrupción de la monarquía británica. Alentaba a los hombres limpios a valerse de la libertad para mantener el espíritu de ésta, protestando contra aquello que no pudieran obstaculizar y reclamando lo

\footnotetext{
${ }^{82}$ Retomamos la selección de autores que menciona Elliot, aunque ésta no es completa. De acuerdo con el testimonio de John Adams, otros autores leídos en 1770 fueron los historiadores Edward Hyde Clarendon y Catherine Macauly. Elliot, Imperios del mundo, pp. 482-483. Liggio, “Editorial”, p. 3.

83 Trenchard y Gordon, “Cato's Letters”, p. xxiii.

${ }^{84}$ Pocock señala que la igualdad de Catón es isonomía. Pocock, El momento maquiavélico, p. 570.

85 Trenchard y Gordon, “Cato's Letters”, vol. 4, p. 63. Pocock, La Ancient Constitution, pp. 247-251.

86 Pocock, El momento maquiavélico, pp. 569-577.
} 
que no les era posible recuperar. Si bien era insoslayable que los hombres debían obedecer las leyes, la ley general del reino así lo exigía, ${ }^{87}$ confiaba en que subsecuentes acuerdos legales mantuvieran vivo el espíritu constitucional, barrera éste del poder arbitrario. $^{88}$

Estos escritos convivieron con la continuada presencia del republicano James Harrington, quien confiaba en el papel de los ciudadanos y no en las cualidades de los aristócratas. Consideraba que la virtud cívica aseguraba el equilibrio del gobierno mixto inglés, y por ella la corrupción del gobierno podía superarse. La Constitución antigua a sus ojos no había sido instrumento suficiente para evitar la degradación moral. Ésta se presentó debido a que la distribución de la autoridad política no guardaba relación con la distribución de la propiedad. La virtud en que pensaba era parte de una república militar en la que gran número de propietarios libres, en condiciones de relativa igualdad y en posesión de las armas, podían arraigar el reparto del poder, equilibrando y estabilizando a la comunidad política. Ellos estarían así en condiciones de practicar la virtud cívica, que entendía como la disposición de cada individuo de poner la espada al servicio de sí mismos y de la comunidad. ${ }^{89}$

El conocimiento de estas posturas, ideas y salidas políticas entre los colonos de América implicó una asimilación crítica. Harrington parecía un faro inconmovible, ${ }^{90}$ Catón (voz de Gordon y Trenchard) y Bolingbroke fueron referentes para caminar con cautela por la vía que proponían. A América había emigrado el miedo a la modernidad y al contagio de la corrupción. ${ }^{91}$ Además, había que considerar las ideas inglesas a la luz del conocimiento que había de autores clásicos, griegos y romanos. Así que

\footnotetext{
${ }^{87}$ Bolingbroke, “The Idea of a Patriot King”, vol. iv, pp. 269 y 239.

88 Bolingbroke, “The Idea of a Patriot King”, vol. iv, p. 271.

${ }^{89}$ Pocock, El momento maquiavélico, pp. 471-480.

90 Kalyvas y Katznelson, Liberal Beginnings.

${ }^{91}$ Рососк, El momento maquiavélico, p. 615.
} 
cuando los publicistas del ambiente americano cavilaron sobre por qué tenían rey - cosa que se preguntaban desde décadas atrás - la respuesta favoreció el cambio. Ese fue un momento en el que el pensamiento crítico a la monarquía era republicano. ${ }^{92}$

El diseño de una propuesta original para la independencia y ulterior organización de las Trece Colonias se hizo sobre la base de esas tradiciones y tesis, incorporadas al calor de una coyuntura que requirió respuestas y adaptaciones rápidas. Las ideas que inspiraron el movimiento de independencia de las Trece Colonias también entrañaron un trabajo de clarificación y consolidación. ${ }^{93}$ Paine, como el resto de los Padres Fundadores, reformuló su concepto de república considerando los debates del siglo xviII, en un proceso que Kalyvas y Katznelson describen como de apropiación, rechazo, adaptación y absorción. ${ }^{94}$

En ese contexto cultural, el panfleto de Paine imprimió un fulminante ataque a la monarquía inglesa y a su concepto de balance constitucional; además dio cauce a variadas formas de inconformidad que se habían expresado recientemente. Al parecer, las protestas populares de carácter tumultuario en Boston y Charleston no desplazaron el predominio de la protesta tradicional. Sin embargo, los "episodios contenciosos”, entendidos como formas de resistencia a las presiones fiscales del Parlamento inglés que siguieron el formato de asambleas toleradas en el pasado, asumieron rasgos novedosos: participación abierta de los colonos y creación de una red de comunicaciones entre ciudades que antes no existía. ${ }^{95}$ Hubo, entonces, convivencia entre protesta tradicional y novedades que dejaron su impronta en el panfleto. Aquí aparecen frases cuidadas, seguidas por otras irritadas y viscerales, rematando con audaces soluciones.

\footnotetext{
92 Kalyvas y Katznelson, Liberal Beginnings, IV parte.

93 Baylin, The Ideological Origins, cap. II.

94 Kalyvas y Katznelson, Liberal Beginnings, IV parte.

95 Tilly, Los movimientos sociales, pp. 45-47 y 55-59.
} 
El escrito en que Paine diagnosticó el imperio de una doble tiranía (la del rey y la de la aristocracia) fue de inmediato controversial. Los detractores reaccionaron aduciendo que las ideas de Common Sense, de ser adoptadas, dirigirían a la democracia, favorecerían la demagogia o la absoluta corrupción. Otras voces las vieron como inviable adopción: una república con gobierno popular sólo podría sobrevivir en países pequeños con comunidades homogéneas. En el campo de los independentistas republicanos hubo también opositores a las propuestas de Paine; le reprocharon proponer un plan de gobierno despreocupado del equilibrio y balance del régimen. ${ }^{96}$

La renuencia al panfleto es comprensible considerando que el escrito fue denso en contenido ideológico, a pesar de su corta extensión. Una lectura global de las tesis lo demuestra. Paine había estructurado el llamado a la independencia y la adopción de la república en cuatro apartados bien relacionados entre sí y con gran coherencia interna. Los dos primeros estaban dedicados a dirigir su ataque contra la monarquía en general y contra la Constitución inglesa en particular. Las dos últimas partes las consagró a evaluar la decisiva situación americana y la altura de sus habitantes para encararla. El texto como un todo sigue una exposición lógica por la que el lector concluye que optar por la independencia de las Trece Colonias significa irremediablemente adoptar la república. Todo el razonamiento se mueve entre premisas acerca de la necesidad del gobierno, el valor del interés, la importancia de la representación, así como la naturaleza imprescriptible de la igualdad y la libertad en tanto derechos naturales.

En la introducción Paine significa el combate inglés a fuego y espada contra las colonias americanas en protesta como un acto de desconocimiento de derechos naturales universales: " $\mathrm{La}$ causa de América es en gran medida la de toda la humanidad". 97

\footnotetext{
${ }^{96}$ BAYLIn, The Ideological Origins, cap. III.

${ }^{77}$ Paine, "Common Sense", p. 5.
} 
Prepara la comprensión de este aserto al apuntar en tono pedagógico que todo gobierno en sí mismo es un mal necesario. A manera de premisas, explica que el origen del gobierno está en la maldad de los hombres y la impotencia de sostener la virtud moral. Se instaura y asume una modalidad o forma para velar por la libertad y seguridad de los miembros de la sociedad. Su fuerza proviene del común interés de dar felicidad a los gobernados. El ejercicio de una representación con frecuencia renovada por elecciones forma el común interés. La elección asegura la fidelidad de los representantes a la voluntad pública. ${ }^{98}$

A partir de tales premisas, Paine argumenta la tesis de imperfección de la Constitución inglesa: favorece convulsiones y conflictos al combinar incompatibles medios de sucesión del poder (hereditario y electivo); no cumple lo que promete, dar seguridad y libertad, puesto que su complejidad impide conocer la causa legal del sufrimiento del pueblo. Abundando señala que la supervisión de poderes entre sí y el balance que debiera producir es falaz porque la monarquía tiende, por dolencia natural, hacia el poder absoluto y tiene un fundamento absurdo; supone al rey más sabio que los comunes, a la vez que encomienda a éstos vigilarlo. En la práctica lo cierto es que "en Inglaterra la voluntad del rey es ley". 99

Luego Paine explica por qué la Constitución inglesa creaba una doble tiranía. La autoridad de la corona, al igual que la de los Lores, proviene de la historia y tradición, no del poder del pueblo. Afirmada y perpetuada en la sucesión hereditaria, yace sobre una injusticia original, un pacto imprudente y antinatural. Carente de todo sustento, hasta el religioso, la monarquía es obedecida por temor al desorden o por superstición. ${ }^{100}$ Paine acusa a tal modo de gobierno de ser causa universal de recurrentes baños

\footnotetext{
${ }_{98}$ Paine, "Common Sense", pp. 6-9.

99 Paine, "Common Sense", p. 11.

100 Paine, "Common Sense", pp. 13-16.
} 
de sangre. Entonces concluye: rey y aristocracia son incompatibles con la libertad del Estado, la que encarnan los comunes. En ellos vive el principio de igualdad original de los hombres y radica únicamente la representación. "[...] Mientras más se aproxima cualquier gobierno a una república, menos ocupación hay para un rey". ${ }^{101}$ Para entonces, la corona engulló poder y virtud de los comunes.

Considerando la circunstancia conflictiva entre América y el gobierno británico, Paine ofrece un horizonte de expectativas trascendente. ${ }^{102} \mathrm{El}$ desacuerdo entre las partes podría tener una resolución de alcance extraordinario en lo espacial y lo temporal; se estaba a las puertas de una nueva era para la política, así como un nuevo método de pensar si se abandonaba la política de reconciliación. Paine pasa entonces a exponer la confianza que deben tener los americanos para ejecutar el desprendimiento: las colonias no adeudaban nada a la corona ni a Inglaterra, ${ }^{103}$ estaba demostrado que ella no podía hacer justicia al continente; era un poder distante e ignorante de la realidad colonial; las resoluciones que se le consultaban resultaban extemporáneas por lejanía geográfica y no podía apelar a derecho de conquista. ${ }^{104}$

A esos inconvenientes Paine enfrentaba la conveniencia que reportaría a América la separación e independencia. América tenía sólidas cualidades: clamó la hermandad con toda la cristiandad europea y fue territorio de asilo de perseguidos civiles y religiosos, con lo que mostró que la política inglesa era

101 Paine, "Common Sense", pp. 6-12 y 19.

102 "The sun never shined on a cause of greater worth. 'Tis not the affair of a city, a country, a province, or a kingdom, but of a continent $[\ldots]$ now is the time of continental union, faith and honor". PAINE, "Common Sense", p. 21. ${ }^{103}$ Paine enfatiza que el gobierno inglés se había enriquecido con el comercio de las colonias; la protección que dio fue para defender su comercio y dominación; su pretensión de dominio continental enemistaba a las colonias con posibles mercados. Además, recordaba que América debía su población a una emigración que procedía de toda Europa. Paine, "Common Sense”, pp. 22-24.

104 Paine, “Common Sense”, p. 29. 
originalmente tiránica. Ahí florecían las riquezas y el comercio que Gran Bretaña refrenó y que amenazaba con las guerras que emprendía. ${ }^{105}$ A partir de ahí Paine se prepara para ofrecer las salidas posibles y sus consecuencias: una reconciliación solo prepararía un futuro desastroso. Siendo el rey inglés un poder arbitrario, enemigo de la libertad, y no pudiendo las colonias hacer sus propias leyes, quedarán en condición de esclavas, perpetuamente inconformes y ridículas peticionarias. América dejaría de crecer porque su interés no era prioritario para la política británica. ${ }^{106}$

La separación era favorecida por verdades sabidas, de sentido común. Era indiscutible que de la niñez se pasaba a la madurez; cada cosa tiene su tiempo; nada es eterno y las constituciones también eran temporales. Así que renovar una relación desventajosa significaba caer en una mayor desgracia. Y la perla: "No hay ejemplo en la naturaleza que haga al satélite más grande que el planeta". ${ }^{107}$

Paine prometía un futuro venturoso: sólo la independencia podía conservar la paz del continente y preservarlo de las guerras civiles. Las colonias tenían un espíritu favorable al buen orden y obediencia al gobierno continental, así como carecían de deseo de superioridad de alguna sobre las otras. Además, una independencia afianzada en un gobierno republicano generaría prosperidad porque negociaría su convivencia con los extranjeros, basada en el respeto a los principios naturales y no en el orgullo e insolencia de las monarquías. ${ }^{108} \mathrm{El}$ plan de ruta de la independencia que propuso Paine haría tangibles esos anhelos. Había que crear espacios de deliberación, instituciones representativas, una Carta Continental que consagrara los principios de la ley por encima de cualquier hombre, igualdad, propiedad

\footnotetext{
105 Paine, “Common Sense”, p. 29.

106 Paine, “Common Sense”, pp. 30-31.

107 Paine, “Common Sense”, pp. 28-29.

108 Paine, “Common Sense”, pp. 32-33.
} 
y libertad de creencias. Ejercer el derecho natural formando un gobierno propio daba la oportunidad de lograr la mayor suma de felicidad individual con el menor gasto nacional. Tocaba ahora hacer de América un asilo de la libertad. ${ }^{109}$

Para ello Paine propuso a los colonos valerse de los abundantes recursos y ambición que tenían para potenciar el comercio. Crear puertos libres, una armada que podría convertirse en la "natural manufactura" y el pivote de oficios subsidiarios, con la ventaja de reunir en ella el comercio y la protección de las costas. El territorio era pródigo para hacerlo y para producir armas. Como ninguna otra, la nación gozaba de vastas tierras desocupadas que aseguraban potenciales ingresos públicos. La población estaba en su juventud, época seminal para buenos hábitos. ${ }^{110}$ Luego de otras recomendaciones, Paine indicó que en la condición de súbditos nadie los podía escuchar, ni sería posible recibir ningún apoyo del extranjero.

El panfleto fue, como es de advertirse, un texto político integralmente concebido para la independencia estadounidense, revolucionando la forma de gobierno, pues de la electividad de la representación dependía la virtud cívica. ¿Qué seleccionó Servando Teresa de Mier de Common Sense en los escritos que nos interesan? Y ¿a qué obedeció esa selección?

\section{COMMON SENSE EN LOS ESCRITOS DE MIER}

La Historia de la revolución en la Nueva España, como se sabe, fue escrita por Mier entre Cádiz y Londres, de 1811 a 1813. Tenía más de 15 años de vivir en internamientos conventuales, reiterados escapes y persecuciones entre España, Francia, Roma y Portugal a consecuencia de la conmoción que provocó la lectura del sermón guadalupano de 1794, primera pieza del patriotismo

109 Paine, “Common Sense”, pp. 33-36.

110 Paine, “Common Sense”, pp. 37-45. 
criollo en la que criticó, desde la tradición española, la legitimidad de la monarquía española. Durante ese lapso confirmó su desprecio por la España que enviaba a "la flor de la nación” a sus cárceles y que mostró ser políticamente ineficaz.

Vivió directamente el tiempo en que la monarquía quedó postrada ante la Francia thermidoriana y napoleónica por los tratados de Basilea (1795) y de Fontainebleau (1807), gastando recursos españoles sin compensación y atestiguando las ambiciones expansionistas de Bonaparte en Europa para imponer el bloqueo continental a los ingleses, sin detenerse ante sus aliados. Conoció los debates conciliares y ocaso de la Iglesia constitucional encabezada por Henri Grégoire. A la vez, amplió su información sobre los temas políticos americanos al entrar en contacto con los primeros exiliados en Europa: Simón Rodríguez, maestro de Simón Bolívar, y el círculo de Francisco Miranda. Experiencias que lo prepararon para definir su postura independentista para la patria americana y lo expusieron al debate entre legitimismo y republicanismo articulado a los escritos de Thomas Paine. ${ }^{111}$

Después de participar en los combates contra el ejército napoleónico, la convocatoria a Cortes extraordinarias llevó a Mier hacia Cádiz, donde tuvo una experiencia decisiva. Desde las márgenes, se unió a los diputados novohispanos y americanos para abrazar la demanda de igualdad de derechos de que disfrutaban los españoles peninsulares, así como propagar escritos en que peticionaron a favor de América y denunciaron su subordinación. Entre otras actividades, ahí Mier conoció escritos de insurgentes e inició la corresponsalía de El Español; tomó nota del "Informe del Consulado de Comerciantes de México", con su tesis de inferioridad de los americanos; leyó los escritos de

111 Saint Lu y Bénassy-Berling (coords.), Historia de la revolución, pp. iv, xv-xvi. Domínguez, La vida de fray Servando, p. 151. Gueniffey, "Un año antes", pp. 18-19. Ocampo, "La influencia extranjera", p. 78. 
Juan José Enrique López de Cancelada, editor de la Gaceta de México y autor de Verdad sabida y buena fe guardada, por el que comenzó a escribir la respuesta a la versión realista de la historia de la Nueva España. ${ }^{12}$

Así que entre febrero y septiembre de 1811 Mier reunió el expediente por el que adquirió el convencimiento de que, en el contexto de las Cortes, "[...] las Américas han de ser eternamente inferiores a España". ${ }^{113}$ La decisión de Mier de trasladarse a Londres dio un giro a sus tareas y objetivos políticos: entrelazó su destino con el de los hispanoamericanos independentistas. Con ello no abandonó el apoyo que daba y recibía de los diputados novohispanos, pero abiertamente se convirtió en ideólogo de la independencia. En octubre de ese año Mier llegó a aquella ciudad para integrarse a los círculos que desde tiempo atrás tenían ésa por causa. Acompañado por Carlos de Alvear y Wenceslao Villaurrutia ingresó a la logia de los Caballeros Racionales número 3, filial en Cádiz de la logia madre, la Gran Reunión Americana, que en 1797 fundó el caraqueño Francisco de Miranda. ${ }^{114}$

De ahí surgieron tres sociabilidades interconectadas que acompañaron a Mier en su actividad. La de los novohispanos sin agente pero económicamente influyentes, aglutinada en torno a los hermanos Fagoaga ${ }^{115} \mathrm{y}$ a una red de informantes directos

112 Mier quedó marcado por la experiencia en las Cortes y la inflexible negativa de atender peticiones de los americanos: representación igual, ciudadanía sin considerar la negritud, igualdad en el empleo, autonomía de las juntas administrativas, restitución de los jesuitas. SAINT Lu y BÉNASSY-BERLING (coords.), Historia de la revolución, pp. xviii-xxii. ZÁrate Toscano, Juan López de Cancelada, pp. 27 y 38.

${ }_{113}$ Citado por Domínguez, La vida de fray Servando, pp. 368-376.

${ }^{114}$ La fundación de esa agrupación secreta en Londres buscaba promover la independencia, el bien de sus provincias y establecer una organización republicana para el gobierno. Jiménez Codinach, La Gran Bretaña, p. 279. Domínguez, La vida de fray Servando, pp. 381-382, 385 y 397-398.

${ }^{115}$ Los miembros de la familia Fagoaga, incluido el Marqués del Apartado, promotores de la independencia, financiaron el círculo venezolano de Miranda y su periódico El Colombiano. Vinculados al grupo Murphy Gordon, fueron 
a la que pertenecía el oaxaqueño Luis de Iturribarría. ${ }^{116} \mathrm{La}$ de oficiales argentinos, independentistas de primera línea, que fue un grupo definitivo que vinculó a Mier al círculo de Londres, entre otros rescates. Carlos de Alvear fue el contacto clave. ${ }^{117}$ Finalmente, la de los venezolanos, grupo más antiguo y afianzado entre sí, que proveyó el primer material para pensar las salidas para América y apoyo para trabajar por la independencia mediante el lazo tendido entre Cádiz y la casa de su líder, Miranda. De entre ellos fue destacada la amistad con Andrés Bello. ${ }^{118}$ Aun cuando no todos fueron republicanos, accionaban para ejecutar su causa, demostrar la justicia de ella y ofrecer oportunidades de un prometedor mercado. ${ }^{119}$

Pero para Mier, el más cercano y duradero amigo en Londres fue White, quien celebró con los lectores de El Español la aparición del manifiesto político, la Historia de Mier. ${ }^{120}$ Para

afectados por la consolidación de vales reales dictada en 1804. Emigraron en 1809. José María fue expulsado de Nueva España en 1815 porque era "el americano más insurgente" y "el implacable enemigo de España”. JimÉNEZ Codinach, La Gran Bretaña, pp. 45, 101 y 276-277. SAint Lu y BÉnassyBerling (coords.), Historia de la revolución, pp. xxxiii-xxxiv. Wobeser, "La Consolidación”, pp. 27-28. Bertrand, "Entre ruptures”, pp. 75-76 y 80-82. Ortuño Martínez, "Hispanoamericanos”, p. 67.

${ }^{116} \mathrm{La}$ red anudaba en Cádiz con informantes relacionados con los Guadalupes. Saint Lu y Bénassy-Berling (coords.), Historia de la revolución, p. xxxviii. Sobre Iturribarría véase Rieu-Millan, Los diputados americanos, pp. 47 y 382 .

117 Tuvo contacto además con San Martín, Manuel Moreno y Tomás Guido, quienes fundaron la Logia Lautaro que desarrolló contactos en Cádiz, Filadelfia, Caracas y Londres. SAINT Lu y BÉnAssy-Berling (coords.), Historia de la revolución, p. xxxii. Domínguez, La vida de fray Servando, p. 398.

118 Perea, Los respectivos alientos, p. 45.

119 Para la importancia a temprana hora del accionar independentista de Francisco Miranda véase Silva Beauregard, "Redactores, lectores”, pp. 147 y 152. ${ }^{120}$ White le dio cobertura en la tertulia de Holland House, punto de encuentro de liberales españoles exiliados. Véanse Calvo Maturana, "Elizabeth Holland", p. 74. SAINT Lu y BÉNASSY-BERLING (coords.), Historia de la revolución, pp. xxix y xxxi. 
ello le había compartido documentación, contactos dentro del mundo de la política y el impreso, así como apoyo económico. Además, intermedió ante el Foreing Office y el gobierno de las Cortes en Cádiz. ${ }^{121}$ No sobra decir que en ese tiempo Mier admiró a la monarquía británica por su indiscutible capacidad de conservación.

Cuando llegó a Londres, Mier llevaba consigo los primeros capítulos de lo que fue la Historia. Es bien conocido que la esposa de Iturrigaray le pidió escribirlos para defender la reputación del exvirrey, manchada en las publicaciones de López Cancelada. Los reorientó cuando decidió escribir la historia de la insurgencia; así los capítulos formaron parte de una obra mayor que finalmente se organizó en 14 libros. ${ }^{122}$ La escritura, retomada en septiembre de 1812, culminó en la Historia, que conoció la luz a finales de $1813 .{ }^{123} \mathrm{La}$ amalgama de intencionalidades que la inspiraron y objetivos con que evolucionó, convirtieron al escrito en texto de batalla. ${ }^{124} \mathrm{La}$ "monumental y confusa historia", ${ }^{125}$ fue un testimonio que buscó sensibilizar la opinión pública británica a favor de la causa americana, pues creía, con el resto de exiliados, que la libertad de América no se conseguiría sin el apoyo de Inglaterra; así que la Historia no aspiró a ser una

${ }^{121}$ Claps Arenas, "José María Blanco White”, pp. 12-20. Jara Gómez, "Blanco White”, pp. 98-103. BREÑA, El primer liberalismo, pp. 400-412.

122 SaInt Lu y BÉNAssy-BERLing (coords.), Historia de la revolución, p. xviii.

${ }^{123}$ La distribución de la obra en América fue desafortunada por el naufragio de la embarcación en la que venía. Mier la reeditó en Estados Unidos junto con Memoria político-instructiva. Beltrán Goren, "Servando Teresa de Mier”, p. 83.

${ }^{124}$ La información de los primeros siete libros se la proporcionan los diputados por la ciudad de México (Beye C.), Guadalajara (Uría), Michoacán (Foncerrada), Zacatecas (Gordoa), Querétaro (Mendiola), Coahuila (Ramos Arizpe), Tlaxcala (Guridi Alcocer). El resto de fuentes provino de los contactos en Londres y constituyó una impresionante masa documental. SAINT Lu y BÉNASSY-BERLING (coords.), Historia de la revolución, pp. xviii y xxxiv-xxxv. ${ }^{125}$ Bertrand, "Entre ruptures", pp. 73 y 79. 
narración objetiva. Fue una obra apologética y un manifiesto político independentista. ${ }^{126}$

En una breve presentación de conjunto, la Historia dedica los siete primeros libros a la defensa del Ayuntamiento de la Ciudad de México y de Iturrigaray; el IV, modificado en 1812, resalta las maniobras de las Cortes contra los americanos, critica la Constitución gaditana y se ocupa de la mediación inglesa. A partir del libro VIII cambia el objetivo y comienza a narrar la insurrección de Hidalgo; ahí da respuesta a Blanco White respecto a la declaración de independencia venezolana y la adopción de la república. Los libros IX y X fueron escritos al calor de la represión contra la Venezuela independentista. Para entonces ha cambiado el tono moderado de los primeros libros y la escritura se torna exaltada; justifica con ardor la independencia sobre la base de la tesis de violación del pacto entre los reyes y América. En el XIII abunda en los horrores de la guerra y entre agosto y octubre de 1813 redacta el último libro de la Historia. ${ }^{127}$

Es en el libro XIV, epílogo de los anteriores, donde Mier retoma a Paine para argumentar la necesidad de independencia de Nueva España y evitar una posible reconciliación. La pista para ubicar ahí las ideas de Paine fue dada por Mier en Memoria político-instructiva, escrita en Filadelfia, vórtice intelectual estadounidense de finales del siglo XviII. Lo expresó así: "El célebre Tomás Payne [sic] los hizo resolver apelando al sentido común [...] yo traduje su alocución acomodándola a nosotros, en el libro 14 de mi historia de nuestra revolución”. ${ }^{128}$ No es el

\footnotetext{
126 Beltrán Goren, “Servando Teresa de Mier”, pp. 75 y 84.

127 Véase el más amplio análisis en la Introducción de SAINT Lu y BÉnAssYBerling (coords.), Historia de la revolución, pp. xiii-lxxxvi. A pesar de la abigarrada escritura, las digresiones, disertaciones bíblicas, comentarios filológicos y cambio de objetivos de la obra, estos autores encuentran tres partes en la Historia de Mier: la refutación a Cancelada, las causas y origen de la revolución en Nueva España y el estado de la cuestión entre americanos y españoles. Véanse también las pp. xxiv-xxvii.

${ }^{128}$ Mier, Memoria político, p. 108.
} 
único autor al que Mier se refiere. En un detenido estudio, Sain Lu y Bénassy-Berling enumeran las variadas y contradictorias influencias en la Historia: Humboldt, Rousseau, Blanco White, Burke, Raynal, Camilo Torres y Miranda. Un análisis profundo de cada uno permitiría precisar los usos de tan variado espectro de autores. De cualquier forma, hay tendencia a considerar a Burke como el más influyente, lo que conllevó a sostener que en 1813 el erudito novohispano parecía simpatizar con una monarquía al estilo británico. ${ }^{129}$

Tenemos dudas al respecto, aun cuando una conclusión semejante no debiera perder de vista el contexto político en que estaba inscrita la obra, ni sopesar que algún guiño pudiera estar condicionado por uno de los públicos al que Mier dirige la obra: el gobierno británico, a quien se quiere atraer en favor de la causa independentista. Creemos que estos factores tenían mucho peso y posiblemente tales insinuaciones fueron hechas por realismo y prudencia política ante los juegos y apuestas de todos los actores en la coyuntura. De cualquier forma, la prioridad retórica de Mier entre 1812 y 1813 no era la forma de gobierno, pues aun entre los insurgentes se estaba decidiendo por optar abiertamente por la independencia. Él no parece ajeno a esta gran tarea. Resulta interesante, de la cita de arriba, que Mier creyera que el panfleto de Paine había decidido a los estadounidenses a optar por la independencia. Hemos visto que ese no fue su poder.

Las dimensiones de la influencia del pensamiento de Paine en Common Sense sobre Mier, de acuerdo con nuestro análisis, son más amplias de lo que hasta ahora se sabe. Para mostrarlo ubicamos las frases en que se ven los ecos de ideas, tesis y párrafos completos que el novohispano adaptó de aquel panfleto que inclinó la voluntad estadounidense hacia la independencia con república. ¿Las apropiaciones incluyeron argumentos

${ }^{129}$ Saint Lu y Bénassy-Berling (coords.), Historia de la revolución, pp. lxiv, lxv, lxx y lxxii. 
republicanos aun sin nombrar la república explícitamente? ¿Qué seleccionó Mier de tan afamado panfleto?

El libro XIV abre con una pregunta central que lo articula: “¿Por qué se está derramando tanta sangre en las Américas españolas?" Este es un cuestionamiento similar al que Paine arguye en la tercera parte de Common Sense..$^{130} \mathrm{La}$ entrada a boca de jarro en la exposición del libro ha prescindido de la situación imaginaria que explica el origen de los gobiernos, formulada por Paine - misma situación que por sus premisas hace ilegítima cualquier monarquía en el orbe. A pesar de dicha omisión y en su estilo abigarrado, a lo largo de las páginas Mier retoma con nuevo instrumental la tarea de deslegitimar a la monarquía española, tal y como esencial y sintéticamente hizo Paine al analizar y criticar la monarquía inglesa, su Constitución, el gobierno mixto y la sucesión hereditaria. ${ }^{131}$

Mier elige el mismo derrotero de Paine, pero singularizándose en tanto que decide encarar su objetivo usando la historia y no el pensamiento lógico. En efecto, Mier vuelve a ocuparse de los textos legislativos que constituyeron la Carta Magna de los americanos; retoma la tesis de independencia del reino ante la ausencia del legítimo soberano; abunda en los 300 años de injusticias, los defectos de la Constitución española liberal y rinde homenaje a fray Bartolomé de Las Casas. ${ }^{132}$ Aquí no advertirá a sus lectores acerca de la importancia de buscar el apoyo de los "extranjeros", como hace Paine; es claro el llamamiento al gobierno inglés, apelando a su amistad activa y a la unidad de los americanos.

\footnotetext{
${ }^{130}$ Sección titulada: "Thoughts on the Present State of American Affairs". J. Guerra, Historia, t. II, p. 161.

${ }_{131}$ Véase la segunda parte de la primera sección, "Of the Origin and Design of Government in General, With Concise Remarks on the English Constitution". También "Of Monarchy and Hereditary Succession".

132 Saint Lu y Bénassy-Berling (coords.), Historia de la revolución, pp. xliv-xlv.
} 
El uso de la historia por el que se inclinó Mier evita que la crítica a la monarquía española se generalice y alcance los terrenos de lo teórico. Sin embargo, el novohispano no deja de apelar a derechos universales desprendidos del iusnaturalismo para responder a su pregunta. Sostiene, como hizo el inglés, que el inicio de las confrontaciones ocurrió cuando la monarquía tuvo una respuesta hostil al ejercicio de derechos, protestas, aspiraciones o deseos de los americanos. A partir de ahí les es común a estos escritores considerar que la agresión monárquica por "naturaleza" condujo a la inmediata proclamación de libertad e independencia de los americanos, en tanto en ninguno de los dos casos hay lugar a reclamos por derechos de conquista. ${ }^{133}$

Asimismo, Mier argumenta que la independencia era la salida digna y el merecido legado a los descendientes, resonando nuevamente el eco de la argumentación de Paine:

Nosotros tenemos el derecho de tomar las armas. Nuestros derechos son la necesidad, una justa defensa, nuestras desgracias, las de nuestros hijos, los excesos cometidos contra nosotros: nuestros derechos son el título augusto de nación. Separémonos y [la nación] ya está formada: la guerra será nuestro único tribunal. Si amamos nuestro país, si amamos nuestros hijos, separémonos: leyes y libertad es la herencia que debemos dejarles. Esta sola causa puede recompensarnos dignamente nuestros tesoros y nuestra sangre. ${ }^{134}$

133 Paine lo refiere con los acontecimientos del 19 de abril de 1775, al calificar la política represiva inglesa de faraónica y al describir la desolación del país provocada por la guerra declarada contra los derechos naturales de la humanidad. Paine, “Common Sense”, pp. 29 y 26, respectivamente. J. Guerra, Historia, t. II, p. 274. Véanse los párrafos de citas 19 y 20 en que sintetizamos la tesis del derecho de gentes.

${ }^{134}$ J. Guerra, Historia, t. II, p. 273. Paine señala que, en su caso, no es posible una salida negociada por el inicio de hostilidades el 19 de abril. Hacerlo era obtener retazos, dejar la espada a los niños, volver atrás empequeñecido y no permitirse la última felicidad. Ningún término podía ser digno al costo de la sangre y tesoro que ya se había vertido. PAine, "Common Sense", pp. 21 y 28. 
Mier tampoco desperdicia otro argumento de Paine en cuanto al orden natural de las cosas y a las potencialidades de las naciones americanas, acomodando las líneas a la situación novohispana: "La naturaleza no ha creado un mundo para someterlo a los habitantes de una península en otro universo [...] ha establecido leyes de equilibrio que sigue constantemente en la tierra como en los cielos. Por la ley de las masas y las distancias la América no puede pertenecer sino a sí misma". ${ }^{135}$

Construyendo sobre argumentos de Paine, Mier repudia una permanencia negociada en la monarquía española. Ello significaría regresar al yugo español, que mostró su rostro de crueldad y violencia; contratar con los verdugos " $i[\ldots]$ nuevas cadenas y cimentar nosotros mismos el edificio de nuestra esclavitud [...]!”. ${ }^{136}$ Si se necesitan leyes, agrega, éstas provendrán del rey o de la nación española, rematando: "[...] Ved sus leyes prohibitivas tan contrarias a los pactos remunerativos de vuestros padres. [...] Ved lo que ha pasado en las Cortes; ella no quiere sino su provecho, y el vuestro la llena de celos”. Mier consideraba que cualquier plan de grandeza y de comercio iniciaría una guerra sorda contra un enemigo "que destruye sin combatir", que originaría la languidez y nutriría la debilidad "[...] y esa es vuestra suerte". ${ }^{137}$ En resumen, ambos avistan la ruina si se produce una reconciliación. ${ }^{138}$

135 J. Guerra, Historia, t. II, p. 277. Paine encontraba absurdo suponer un continente perpetuamente gobernado por una isla. Sostenía que en la naturaleza no había ejemplo de un satélite más grande que su planeta. Inglaterra y América invierten el orden común de la naturaleza; pertenecen a diferentes sistemas: Inglaterra a Europa, América a sí misma. PAIne, "Common Sense”, p. 28. ${ }^{136}$ J. Guerra, Historia, t. II, pp. 273-274. Los siguientes entrecomillados corresponden a estas páginas.

137 Al respecto Paine sostenía que el deseo de leyes podía esclavizar a América, aun sometiéndose a leyes propuestas por los americanos y hechas por ellos en Inglaterra. Había que ir al revés, de lo contrario estarían perpetuamente en disputa o serían ridículamente peticionarios. PAINE, "Common Sense”, p. 30. 138 Mier dice: “¿Queréis saber cuál sería el fruto de un convenio? Vuestra 
Además de señalar que un reencuentro negaría lo que, a ojos de Mier, ya era un hecho, apasionadamente también señalaba su inconveniencia porque arrastraría a Nueva España, por su dependencia renovada, a las guerras europeas en que España continuamente estaba envuelta. Aquí tampoco hubo originalidad; Paine había sostenido el mismo argumento. ${ }^{139} \mathrm{La}$ conclusión es la misma para ambos. No era de interés comercial el estar en estado de guerra con naciones que no habían propinado agravio alguno; la neutralidad era la mejor posición. ${ }^{140}$

Siguiendo el estilo de Paine, Mier anima la confianza de los americanos indicando que a ellos les depara el mismo fin que obtuvieron otras experiencias independentistas exitosas. Se refiere a las Provincias Unidas de los Países Bajos y a los Estados Unidos; ${ }^{141}$ pero aquí omite que ellas fueron experiencias republicanas. Lo que quiere transmitir es la esperanza en un futuro promisorio con acordar la independencia; y aquí no deambula Paine, casi habla:

Jamás un interés más grande ha ocupado a las naciones. No se trata del de una villa o provincia, es el de todo un continente inmenso, o de la mitad del globo. No es el interés de un día, sino el de siglos. Lo presente va a decidir de un largo porvenir, y muchas centenas de años después que nosotros hayamos dejado de existir, el sol, alumbrando este hemisferio, esclarecerá nuestra vergüenza o nuestra gloria. Largo tiempo hemos hablado de reconciliación y paz. Desde que se tomaron las armas, desde que la primera gota de sangre ha

ruina". Paine dice lo propio: "Reconciliation and ruin are nearly related”. J. Guerra, Historia, t. II, p. 273. Paine, “Common Sense”, p. 31.

${ }^{139}$ J. Guerra, Historia, t. II, p. 274. Igual criterio era el de Paine. Paine, "Common Sense", p. 24.

${ }^{140} \mathrm{~J}$. Guerra, Historia, t. II, p. 300. Paine apuntaba esa idea señalando que el comercio requería paz y amistad con Europa, y el interés de ésta era que América fuera puerto libre. PAIne, "Common Sense”, p. 24.

${ }^{141}$ J. Guerra, Historia, t. II, p. 300. 
corrido, pasó ya el tiempo de las discusiones. Un día ha hecho nacer una revolución, un día nos ha transportado en un siglo nuevo. ${ }^{142}$

La expectativa por ese futuro deslumbrante que avizora Mier, al igual que Paine, traspasa la línea de la voluntad y el deseo. Es más que una utopía, es un destino inevitable. Para decirlo, Mier roba otra frase acomodándola a su circunstancia, cuando pronostica que la autoridad de España sobre América finalizará tarde o temprano:

[...] Así lo quiere la naturaleza, la necesidad y el tiempo. España está demasiado lejos para gobernarnos. Qué! ¿Siempre atravesar millares de leguas para pedir leyes, para reclamar justicia [...]? Qué! $¿$ Aguardar durante años cada respuesta, y al cabo no hallar del otro lado del océano sino la injusticia? No, para grandes Estados es necesario que el centro y la silla del poder estén dentro de ellos mismos. Sólo el despotismo del oriente ha podido acostumbrar pueblos a recibir sus leyes de amos remotos, o de Baxaes que representan tiranos invisibles. Pero no lo olvidéis jamás: más la distancia aumenta, más el despotismo abruma y los pueblos entonces privados de [...] casi todas las ventajas del gobierno, no tienen sino las desgracias y los vicios. ${ }^{143}$

En el libro XIV de la Historia, Mier se apropia de ideas, líneas, argumentos de Paine y les introduce mayor dramatismo

142 J. Guerra, Historia, t. II, p. 272. Paine decía que el sol nunca brilló sobre una causa de tan gran dignidad. No es el negocio de una ciudad, un país, una provincia o un reino, sino de todo un continente, de al menos la octava parte de los habitantes del globo. Tampoco era la preoupación de un día, de un año o una época, sino de la posteridad. Paine, "Common Sense", p. 21.

${ }^{143}$ J. Guerra, Historia, t. II, pp. 272-273. Paine sostenía que siempre había considerado que la independencia del contienente ocurriría más temprano que tarde. En otro pasaje señaló que en materia de gobierno el poder británico no hacía justicia, era engorroso y muy dilatado el manejo de los negocios por la distancia e ignorancia de las necesidades. Agregaba que si ellos no nos habían conquista, ellos no podían gobernarnos. PAINE, "Common Sense", p. 28. 
contestatario al instalarse en una lógica de víctima-victimario. Ha leído con cuidado a Paine pero sólo recupera enunciados independentistas. $\mathrm{Ha}$ argumentado a favor de una independencia absoluta. La justifica, quiere hacer ver sus bondades y la establece como una realidad. El tono y las apropiaciones que Mier hace de Paine dejan ver la popularidad que alcanzó aquel panfleto de 1776 en la América española décadas después de su producción. El libro XIV comparte, entonces, la explicación de los hechos como producidos por un sentido natural y por derechos inobjetables. Contiene la confianza de sus autores en un horizonte conveniente y prometedor. No se trata sólo de mostrar que la separación es el destino de los territorios hispanoamericanos, ni de señalar al público inglés las bondades de un comercio libre. Mier se dirige a los americanos y novohispanos para alentar a los que están en la lucha y para convencer a los que dudaban de por qué era posible pensarse independientes.

Pocos meses después de la publicación de la Historia de Mier, la correlación de fuerzas en Europa y América no favoreció las metas de los independentistas hispanoamericanos. Desde mediados de 1813 hubo una progresiva retirada del ejército francés del suelo español y las fuerzas al mando de Wellington obligaron a José I a abandonar su reino. En diciembre Napoleón barajó la alternativa de liberar a Fernando VII, lo cual se concretó en marzo siguiente. Aun cuando la restauración absolutista decretada en mayo de 1814 no alcanzó a estabilizar el régimen, ${ }^{144} \mathrm{y}$ España se integró tardíamente a la Santa Alianza para restablecer el orden político trastornado por Napoleón, Inglaterra quedó comprometida a evitar respaldos abiertos a movimientos secesionistas de sus aliados por el Congreso de Viena.

Por otra parte, el curso de la guerra por la independencia en el sur de América no terminaba de definirse ni de dar frutos; no faltaron serios reveses. Las dos repúblicas que surgieron con la

${ }^{144}$ Fontana, La época del liberalismo, pp. 73-78 y 87-90. 
declaración de independencia de Venezuela - la primera bajo el liderazgo de Miranda, la segunda encabezada por Bolívarfracasaron en 1814. La lucha reviviría medianamente al retornar el futuro Libertador tres años después, comprometido con una movilización militar que ligó su destino a la derrota de los realistas en Nueva Granada, Quito y regiones del Alto Perú. En cuanto a la independencia del virreinato del Río de la Plata, la situación no era mejor. El control de los poderes de Buenos Aires por los patriotas tampoco derivó en la inmediata ruptura; en cambio, desde 1812 se sucedieron confrontaciones internas, movimientos secesionistas y fragmentación político territorial que desplazó liderazgos militares y pospuso la reorganización de la nueva nación. ${ }^{145}$

No obstante, Mier, que permanecía en Londres - con una estancia corta en París - mantuvo el aliento independentista. Los whigs habían dejado abiertas las puertas a los liberales españoles refugiados, por las que Blanco White y Flores de Estrada continuaron recibiendo a españoles perseguidos, entre los que llegó Xavier Mina, quien fue cobijado en Holland House. Entre abril de 1815 y mayo de 1816 fue preparada la expedición para ponerse al servicio de Morelos dirigida por Mier y Mina con apoyos financieros de los whigs y del marqués del Apartado. Los reclutas tenían diferentes procedencias. El desastre que siguió condujo a Mier hacia un nuevo encarcelamiento, esta vez acusado de actos contra Su Majestad. ${ }^{146}$ Una nueva escapatoria (1820), durante el traslado a la prisión peninsular, llevó a Mier hacia los círculos exiliados de Filadelfia. Para entonces había abandonado toda moderación política, apostando definitivamente por la república apoyándose en Paine.

${ }^{145}$ Halperín Donghi, Historia de América Latina, pp. 124-132, 136-140, 155-162 y 175-178.

${ }^{146}$ Jiménez Codinach, La Gran Bretaña, p. 274. Ortuño Martínez, "Recuperación de Xavier Mina”, pp. 94-102. Claps Arenas, "José María Blanco White", p. 35. Domínguez, La vida de fray Servando, pp. 485-492. 
Los hispanoamericanos exiliados en Estados Unidos continuaban buscando apoyo a su lucha independentista, reconocimiento político y nexos para el ulterior florecimiento comercial en un contexto internacional que no les favorecía, pues el gobierno estadounidense tampoco quería granjearse una enemistad sobre un proyecto de dudoso resultado. A pesar del escepticismo sobre la capacidad para autogobernarse, los estadounidenses no dejaron de estar interesados en los objetivos señalados. Ellos también tenían sus intereses; en particular aspiraban a evitar que el comercio en el continente fuera controlado por los ingleses. Igualmente percibieron que un abierto pronunciamiento por la independencia, acompañado por la adhesión a la república, afianzaría su propio destino. ${ }^{147}$

Mier escribe y publica entre 1820 y 1821 la Memoria políticoinstructiva en Filadelfia, ciudad que fue el centro del exilio americano favorable a la independencia y a la propagación de repúblicas en todo el continente. ${ }^{148} \mathrm{~A}$ diferencia del escrito anterior, este fue dirigido a los líderes insurgentes e independentistas para animar la bandera republicana y desechar la opción iturbidista. La Memoria fue escrita en un tono persuasivo y crítico, a diferencia de la Historia. Aquí Mier parece haber encontrado su voz: mucho más directa, personal y original. Con un dramatismo atenuado, el novohispano decididamente centra la mirada del lector en la república como condición para consolidar la independencia absoluta; una acompaña a la otra. Hemos de enfatizar que todo gira alrededor de un mismo punto: un rotundo rechazo a la monarquía. Por ello, vuelve a la argumentación de Paine de manera integral sin abandonar la costumbre de usar la historia. Ya no se trataba sólo de defender la justicia de un derecho o de mantener un hecho. Había que asegurar el nuevo horizonte.

${ }^{147}$ Jiménez Codinach, La Gran Bretaña, p. 112. McNally, "La prensa de los Estados”, pp. 164-167.

${ }^{148}$ Rojas, “Traductores”, pp. 206 y 219. 
Los estudiosos han dividido la estructura del texto de la Memoria en dos. En la primera parte Mier hace un recuento de los acontecimientos recientes en Europa y América hasta el Plan de Iguala. La segunda, más extensa, la dedica a señalar los inconvenientes y prejuicios de adoptar una monarquía como sistema de gobierno. ${ }^{149}$ El repaso de lo sucedido en Europa y en Hispanoamérica desde 1815 da sentido al título del escrito; en efecto, es una memoria. El uso de la historia reciente tiene por meta mostrar los intereses contrarios que Europa tiene con América en general, reproduciendo la perspectiva antagónica. La formación de la Santa Alianza en 1815 lo muestra: tiene objetivos contrarios a los deseos independentistas de América. Para él, la Gaceta de Madrid de 1817, lo confirma. ${ }^{150}$ Incluida la España fernandina en esta asociación, Europa apuesta a perpetuar un sistema colonial calculado para reproducir la humillante esclavitud de América. Así, la Europa monárquica está situada en uno de dos polos opuestos. Simultáneamente, el texto reubica al aliado benefactor de la independencia. Debido a la desilusión de no haber recibido su ayuda, Inglaterra ha sido desplazada por Estados Unidos en ese papel y el sistema republicano es el que Mier promueve abiertamente, porque cree que a él se debe la prosperidad y virtud de ese pueblo. Un futuro fundado en el pasado reciente, el de las reuniones y congreso de los insurgentes que definieron su proyecto político entre 1813 y 1814, no en el Plan de Iguala.

En la estructura de la argumentación resuena fuerte una lectura completa de Common Sense. Mier, como Paine, volvía sobre algunas cuestiones ya tratadas en la Historia: ¿cuál era la utilidad de ser colonos españoles? Era absurdo que la autoridad

149 Beltrán Goren, “Servando Teresa de Mier”, pp. 84-85.

150 "El tiempo ha llegado de que las Cortes de Londres, Viena y Petersburgo obren conforme a sus verdaderos intereses, reconociendo que no habrá seguridad alguna para los gobiernos reales, si se sufre otro [movimiento] independiente en América”. Mier, Memoria político, p. 7. 
sobre la Nueva España viniera desde la Península. Nueva España, como las Trece Colonias, era satélite colonial gobernado a lo lejos por un país europeo preocupado más por los intereses de quien gobierna que por fomentar el progreso tanto de la colonia como de la metrópoli. La desventaja de permanecer dependiente de una monarquía a distancia la resumió en la Memoria con esta frase:

¿De qué nos sirve España? De envolvernos en sus guerras y calamidades sin que nos pertenezca su objeto, de pedirnos dinero y enviarnos mandones y empleados; es decir, ladrones y verdugos, siempre impunes, porque es axioma del gobierno español, que cuanto hagan sus agentes en América, bueno o malo, ha de ser sostenido, para que sea respetada la autoridad a lo lejos. ${ }^{151}$

Lo nuevo fue incorporar consideraciones antimonárquicas. El despotismo e intransigencia españoles con respecto a los deseos de las colonias americanas sólo puede enfrentarla una América libre e independiente sostenida por valores republicanos. La monarquía, escribe Mier, es un sistema nefasto para la nueva nación; los gobiernos de reyes "son verdaderamente unos ídolos manufacturados por el orgullo y la adulación”. ${ }^{152}$ Deja claro que el obstáculo para el progreso económico de la Nueva España era estar sujeto a la España monárquica, por lo cual no había razón que justificara la continuación de la dependencia con la corona. ${ }^{153}$

151 Mier, Memoria político, pp. 120-121.

${ }^{152}$ Mier, Memoria político, p. 46. Es reiterado este juicio en Paine. No sólo considera a la monarquía propensa al orgullo y la insolencia, sino también a la incompetencia y capricho del titular del trono. PAIne, "Common Sense", pp. 13-16.

${ }^{153}$ Paine escribió: "America would have flourished as much, and probably much more, had no European power had anything to do with her". Luego decía: "We [America] are already greater than the king wishes us to be". PAINE, “Common Sense”, pp. 22 y 30. 
El contexto internacional en que escribía fue oportuno para que Mier, sin más argumentos que el de la historia, llegara a una de las tesis fuertes de Paine; es decir, ser de causa natural que al independizarse los mexicanos adoptaran simultáneamente la república. Al estudiar los gabinetes e intereses de Europa, decía, le quedó claro que "están en contradicción con los de América, especialmente en caso de ser republicana” ${ }^{154}$ Libertarse bajo esa última forma de gobierno evitaría quedar enredado en las guerras innecesarias de Europa. La contradicción entre un continente y otro no era más que expresión clara de la diferencia entre sistemas: monarquía europea y república americana. ${ }^{155}$ A esas alturas Mier asumía con Paine que la cualidad natural del sistema monárquico era "romper las barreras y extender los límites de su autoridad"; ${ }^{156}$ la monarquía era lo opuesto a la libertad.

La oposición de gobiernos permite a Mier hacer propia la postura continentalista de Paine. Los intereses de los mexicanos son los de América: "No son los de Europa los suyos sino los de sus hermanos del continente americano". ${ }^{157}$ Igualmente el objetivo de la independencia de Mier en la Memoria yace bajo un argumento similar al de Paine: darse sus propias leyes, sin que un rey las dicte a capricho. ${ }^{158}$

En el momento en que en este escrito Mier se acerca a las radicales propuestas que condensaban el pensamiento integral de Paine en Common Sense, más se aleja de ese pensamiento. Es decir, Mier retomó los argumentos de Paine para fundamentar la

\footnotetext{
154 Mier, Memoria político, p. 89.

155 Paine aludía a los sistemas opuestos a que pertenecían Inglaterra y América, tanto como a los diferentes continentes. PaIne, "Common Sense”, p. 28.

156 Mier, Memoria político, p. 75. Paine escribía con palabras rudas esta misma opinion. Paine, “Common Sense”, p. 18.

${ }_{157}$ Mier, Memoria político, p. 14. Paine, Common Sense, p. 28.

158 Paine preguntaba si por independencia se quería decir que los americanos debían hacer sus propias leyes o si debía decir el rey, el más grande enemigo del continente, "ahí no debe haber más ley que lo que quiero". PAIne, "Common Sense”, p. 30.
} 
república sin su republicanismo. Al retomar la fórmula política no alude a la representación electiva ni a las correspondientes instituciones, a los espacios de la deliberación, a la libertad de creencias o al principio de igualdad que distinguieron al pensamiento republicano de Paine. Ese movimiento no sabemos si fue voluntario. Probablemente no perdió de vista que algunos de esos puntos estaban contenidos en la Constitución gaditana vigente. El hecho es que enfrentaba en el escrito una voluntad mayoritaria en Nueva España que buscaba mantener un gobierno monárquico vínculado con la dinastía borbónica para abrazar la independencia, que a ojos de Mier no era absoluta: los artículos $3^{\circ}$ y $4^{\circ}$ del Plan de Iguala contradecían el artículo $2^{\circ}$.

Aun así, una declaración republicana podía asegurar el deseado respaldo del gobierno extranjero del vecino del norte para mantener la independencia; Paine había prometido convertir a América en asilo de la libertad. ${ }^{159}$ Mier parece posponer para el momento constitucional las definiciones sustantivas del republicanismo. En 1823 había de defender que adoptar la república no era asunto de imitación acrítica. Había que elegir lo ventajoso y desechar las deficiencias de ese modelo fue su consigna. O’Gorman lo resalta: "Esta variante de opinión es el fundamento del llamado centralismo del padre Teresa de Mier" ${ }^{160}$ Brading compartió dicha opinión. ${ }^{161}$ No fue, en otros términos, ingenuo en sus elecciones.

\section{CONCLUSIÓN}

El recorrido por el capítulo XIV de Historia de la revolución en la Nueva España y por la Memoria político-instructiva de Servando Teresa de Mier nos permite concluir, en relación

${ }^{159}$ Paine, “Common Sense”, pp. 33-36 y 52.

160 O'Gorman, Servando, p. xxxi.

161 Brading, Orbe indiano, p. 645. 
con la influencia de Thomas Paine que no representaron dos momentos de evolución del pensamiento del autor. Fueron formulaciones específicas relacionadas con lo que era admisible escuchar. Es decir, el contexto de producción de los dos escritos fue decisivo para elaborar las propuestas que se expusieron. Mier no fue un independentista encantado por la experiencia republicana en Norteamérica; usó deliberadamente fragmentos y tesis secundarias de Common Sense en dos momentos de su propaganda política a favor de la independencia absoluta: al publicar en Londres en 1813 y al redactar y publicar en Filadelfia en 1821. Las apropiaciones selectivas que hizo siguieron de cerca los ritmos de evolución de los ánimos en Nueva España y el juego de fuerzas internacional.

Nuestra indagación sugiere que en 1813 no fue necesario usar la carta republicana de Paine. En el marco de una situación de fragilidad imperial española, había que atraer la protección de Inglaterra y encarar el hecho de que aún no predominaba la voluntad independentista entre los novohispanos, así que arraigar tal voluntad fue la prioridad. La Historia de Mier tenía por interlocutores al gobierno inglés, pero también a las élites cultivadas de los novohispanos; a ellas igualmente había que persuadirlas de la razón, justicia y necesidad de la separación. Un escrito de tales proporciones y con el estilo que adquirió parece ineficaz para lograr esa meta entre un gran público, que por cierto no fue amplio. Libertad natural, derechos naturales de las personas morales e independencia, bastaban para apuntalar el manifiesto político independentista.

Al momento en que la voluntad independentista ganó terreno entre los novohispanos, Mier recuperó la decisión del Congreso de Chilpancingo, plasmada en la Constitución de Apatzingán. Entonces identificó independencia con república, en una asimilación de la fórmula política de Paine, convirtiéndo esos términos en parte de un binomio inseparable. Memoria político-instrutiva volvió a fundamentar la justicia y necesidad 
de independencia absoluta; volvió a adaptar parte de la argumentación del panfletista inglés en un contexto de gran prestigio del plan iturbidista con su invocación a la union y hermandad con la España monárquica. En contraste, Mier refirió a los comunes objetivos y características que Nueva España tenía con el vecino del norte. Estados Unidos era, en 1821, la nueva personificación de la potencia extranjera con la que aliarse y proteger a las nuevas naciones plenamente soberanas, que tanto buscaron los hispanoamericanos desde 1811 en Londres. Pero el término república, apropiado por Mier en la Memoria, fue vaciado del republicanismo de Paine. En el escrito, esa voz no connotaba representación, ni libertades para la deliberación, ni el principio de igualdad. No obstante, Mier encontró en la historia reciente argumentos antimonarquistas que hicieron factible apropiarse de aquel binomio y que implicaban los rasgos de corrupción del gobierno.

Los fragmentos de Common Sense que Mier atrajo a sus escritos, con los conceptos políticos que contenían, fueron adaptados efectivamente al contexto de producción en que escribió. Al hacerlo, no traicionó la tradición política en donde había crecido. Hizo uso ejemplar del estilo, de las ideas y argumentos de Paine en 1776, utilizando el panfleto. La selección de Mier atendió a la urgencia de mover la balanza a favor de la independencia absoluta, apelando al iusnaturalismo que reclamó para las colonias españolas, como lo tuvieron las inglesas, de buscar un camino diferente a la sujeción colonial. Es posible que también la sangre aristocrática que corrió en las venas de Mier haya impedido asumir los argumentos igualitarios de Paine y recoger cabalmente la propuesta republicana del panfleto de 1776, ya de por sí radical. Ciertamente los tintes sociales, liberales, representativos, no encontraron lugar en la Memoria de Mier.

De cualquier forma, las ideas apropiadas no quedaron fuera de lugar. La joven república estadounidense en 1821 iluminaba un camino hacia un futuro próspero. Aquellas ideas entonces 
lograron aterrizar y las más extranjeras tuvieron su tiempo para germinar. La paráfrasis, el traslado de argumentos, apropiación y resignificación de conceptos del pequeño panfleto escrito en 1776 ayudó a Nueva España a conquistar la anhelada meta: independizarse. La república, despojada de sustancia republicana, pronto tuvo lugar una vez que otro sueño, el imperial, se derrumbó.

\section{REFERENCIAS}

Altamirano, Carlos (dir.), Historia de los intelectuales en América Latina, Buenos Aires, Katz editores, 2008, vol. I, Myers (ed.), La ciudad letrada. De la conquista al modernismo.

Ávila, Alfredo, “Servando Teresa de Mier”, en Clark de Lara y Speckman GUERRA (coords.), 2005, pp. 9-22.

Ávila, Alfredo, Juan Ortiz Escamilla y José Antonio Serrano Ortega, Actores y escenarios de la Independencia. Guerra, pensamiento e instituciones, 1808-1825, México, Fondo de Cultura Económica, Museo Soumaya, Fundación Carlos Slim, 2010.

Baylin, Bernard, The Ideological Origins of the American Revolution, Cambridge, The Belknap Press, Harvard University Press, 1992, edición electrónica.

Beltrán Goren, Yael, "Servando Teresa de Mier”, en Ortega y Media y Camelo (coords.), 1997, pp. 65-93.

Bergeron, Louis, François Furet y Reinhard Koselleck, La época de las revoluciones europeas, 1780-1848, México, Siglo Veintiuno editores, 1979.

Bertrand, Michel, "Entre ruptures et tradition: les cheminements de Fr. Servando face à la crise d'independence", en Caravelle. Cabiers du Monde Hispanique et Luso Brasilien, 67 (dic. 1996), pp. 73-88.

Bolingbroke, Henry St. John, Lord Viscount, "The Idea of a Patriot King”, (1737), en The Works of the Late Right Honourable Henry St. John, Lord Viscount Bolingbroke, Londres, impreso por J. Johnson, Otridge \& Son, Faulder \& Son, 1809.

Brading, David, Orbe indiano. De la monarquía católica a la república criolla, 1492-1867, México, Fondo de Cultura Ecoonómica, 1991. 
BREÑA, Roberto, El primer liberalismo y los procesos de emancipación de América, 1808-1824. Una revisión historiográfica del liberalismo hispánico, México, El Colegio de México, 2006.

Calvo Maturana, Antonio Juan, "Elizabeth Holland: portavoz de los silenciados y cómplice de ese tópico", en Cuadernos de Historia Moderna, 29 (2004), pp. 65-90.

Claeys, Gregory, Thomas Paine. Social and Political Thought, Boston, Unwin Hyman, 1989.

Claps Arenas, María Eugenia, "José María Blanco White y la «cuestión americana»", en Estudios de Historia Moderna y Contemporánea de México, 29 (ene.-jun. 2005), pp. 5-40.

Clark, Harry Hayden, “Thomas Pane's Theories of Rhetoric”, en Transactions of Wisconsin Academy of Science [en línea], XXviII (1933), pp. 307-312. Consultado el 24 de noviembre de 2015.

Clark de Lara, Belem y Elisa Speckman Guerra (coords.), La República de las Letras. Asomos a la cultura escrita del México decimonónico, México, Universidad Nacional Autónoma de México, 2005.

Clegg, Cyndia Susan, "Joad Raymond, Pamphlets and Pamphleteering in Early Modern Britain”, en The American Historical Review, 109: 2 (abr. 2004), pp. 608-609. http://www.jstor.org/stable/10.1086/530490. Consultado el 18 de febrero de 2016.

Coronas GonzÁlez, Santos M., "Leyes fundamentales y constitución de la monarquía española de 1812", en Iura Vasconiae, Revista de Derecho Histórico y Autonómico de Vasconia, 8 (2011), pp. 41-62.

Chartier, Roger, “El hombre de letras”, en Vovelle, 1992, pp. 151-195.

Chiaramonte, José Carlos, Nación y Estado en Iberoamérica. El lenguaje politico en tiempos de las independencias, Buenos Aires, Sudamericana, 2004.

CHIsIck, Harvey, "Pamphlets and Journalism in the Early French Revolution: The Offices of the Ami du Roi of the Abbé Royou as a Center of Royalist Propaganda", en French Historical Studies, 15: 4 (otoño 1988), pp. 623-645.

DARNTON, Robert, El beso de Lamourette: reflexiones sobre historia cultural, Buenos Aires, Fondo de Cultura Económica, 2011.

DARNTON, Robert, Edición y subversión. Literatura clandestina en el Antiguo Régimen, México, Fondo de Cultura Económica, Turner, 2003. 
Diego Fernández, Rafael, "Influencias y evolución del pensamiento político de fray Servando Teresa de Mier”, en Historia Mexicana, xLviII: 1 (189) (jul.sep. 1998), pp. 3-38.

Domínguez, Christopher, La vida de fray Servando, México, Era, Conaculta, Instituto Nacional de Antropología e Historia, 2004.

Elliot, John, Imperios del mundo atlántico, Madrid, Santillana Ediciones Generales, 2009.

ELLIs, Joseph, Founding Brothers. The Revolutionary Generations, Nueva York, Vintage Books, 2002.

ELLIs, Richard J., "Radical Lockeanism in American Political Culture”, en The Western Political Quarterly, 45: 4 (dic. 1992), pp. 825-849. http://www.jstor. org/stable/448814. Consultado el 25 de abril de 2012.

Estrada Michel, Rafael, "La teoría constitucional en la profecía del padre Mier sobre la federación mexicana", en Anuario Mexicano de Historia del Derecho, XI-XII (2000), pp. 23-81.

Foner, Eric, Tom Paine and Revolutionary America, Oxford, Oxford University Press, 1977.

Foner, Eric (ed.), Thomas Paine: Collected Writings, Nueva York, The Library of America, 1955.

Fontana, Josep, La época del liberalismo, Barcelona, Crítica, Marcial Pons, 2007, vol. 6 de Historia de España, J. Fontana y R. Villares (dirs.).

FRAIRE, Isabel, Pensadores norteamericanos del siglo XIX. Una antología general, México, Siglo Veintiuno editores, 2004.

Fruchtman, Jack, The Political Philosophy of Thomas Paine, Baltimore, The John Hopkins University Press, 2009.

González Troyano, Alberto, "Los libelos ilustrados en el Cádiz romántico. Los panfletos liberales de Bartolomé José Gallardo”, en Anales de la Universidad de Cádiz, 2 (1985), pp. 367-374.

GuedeA, Virginia (comp.), La revolución de independencia, México, El Colegio de México, 1995.

Gueniffey, Patrice, “Un año antes: Napoleón en España, 1808”, en Istor, 10: 38 (2009), pp. 3-30. http://www.istor.cide.edu/archivos/num_38/dossier1.pdf. Consultado el 3 de diciembre de 2016. 
Guerra, François-Xavier, “Lógica y ritmos de las revoluciones hispánicas”, en Guerra (dir.), 1995, pp. 13-46.

Guerra François-Xavier (dir.), Las revoluciones hispánicas: independencia americana y liberalismo español, Madrid, Complutense, 1995.

Guerra, José, Historia de la revolución en Nueva España antiguamente Anáhuac, o verdadero origen y causas de ella, con la relación de sus progresos hasta el presente año de 1813. Edición tomada literalmente de la primera hecha en Londres, Imprenta de Guillermo Glindon, 1813, dos tomos. Con anotaciones del Dr. Servando Teresa de Mier Noriega y Guerra.

Halperin Donghi, Tulio, Historia de América Latina, reforma y disolución de los imperios ibéricos, Madrid, Alianza América, 1985, vol. 3.

Hamnett, Brian, "Process and Pattern. Re-Examination of the Ibero-American Independence Movement, 1808-1826”, en Journal of Latin America Studies, 29: 2 (mayo 1997), pp. 279-328.

Harrington, James, “The Commonwealth of Oceana”, en Toland (ed.), 1737, pp. 30-228.

Hernández Prado, Juan, “Alcances y limitaciones de la concepción arendtiana del sentido común”, en Sociológica, Xvi: 47 (sep.-dic. 2001), pp. 126-156 [en línea]. Consultado el 23 de enero de 2015.

HobsBawm, Eric, Uncommon People: resistance, rebellion and jazz, Londres, Weidenfeld \& Nicolson, 2011, edición electrónica.

Ibarra, Ana Carolina, El cabildo de Antequera. Oaxaca y el movimiento insurgente, Zamora, El Colegio de Michoacán, 2000.

Ibarra, Ana Carolina, “Excluidos pero fieles. La respuesta de los insurgentes a las sanciones de la Iglesia, 1810-1817”, en Signos Históricos, Iv: 7 (ene.-jun. 2002), pp. 53-86.

IbARra, Ana Carolina, “"La justicia de la causa»: razón y retórica del clero insurgente de la Nueva España”, en Anuario de Historia de la Iglesia, 17 (2008), pp. 63-80.

JARA Gómez, Ana M., "Blanco White: un militante contra el absolutismo. Del liberalismo a la cuestión colonial”, en Espiral, Estudios sobre Estado y Sociedad, xxi: 61 (sep.-dic. 2014), pp. 87-107.

Jiménez Codinach, Guadalupe, La Gran Bretaña y la independencia de México (1808-1821), México, Fondo de Cultura Económica, 1991. 
Jovellanos, Gaspar Melchor, "Discurso sobre la necesidad de unir al estudio de la legislación el de nuestra historia y antigüedades", en Obras históricas, México, Porrúa, 1993, pp. 7-24.

Kalyvas, Andreas e Ira Katznelson, Liberal Beginnings. Making a Republic for the Moderns, Nueva York, Cambridge University Press, 2008, edición electrónica.

KATCHER, Brian, "Benjamin Rush's Educational Campaign against Hard Drinking”, en American Journal of Public Health, 83: 2 (feb. 1993), pp. 273-281.

Kramnick, Isaac, “Thomas Paine: Radical Liberal”, en Republicanism and Bourgeois Radicalism, Ithaca, Londres, Cornell University Press, 1990.

LAmbert, Paul F., "Benjamin Rush and American Independence”, en Pennsylvania History: A Journal of Mid-Atlantic Studies, 39: 4 (oct. 1974), pp. 443-454.

Liggio, Leonard P., "Editorial”, en Literature of Liberty, A Review of Contemporary Liberal Thought, III: 2 (verano 1980), pp. 3-4.

MaYer, Alicia (coord.), México en tres momentos, vol. II. Los derroteros de la economía, México, Universidad Nacional Autónoma de México, GM Editores, Espejo de Obsidiana, 2007.

Maza, Sarah, "Le Tribunal de la nation: les memoires judiciaries et l'opinion publique à la fin de l'Ancien Régime", en Annales. Histoire, Sciences Sociales, 42: 1 (ene.-feb. 1987), pp. 73-90. http://www.jstor.org/stable/27583453. Consultado el 19 de febrero de 2016.

McNally, Brenda, "La prensa de los Estados Unidos y la independencia hispanoamericana”, en GuEdEA (comp.), 1995, pp. 156-186.

Mier, Servando Teresa, Memoria politico-instructiva, enviada desde Filadelfia en agosto de 1821, a los gefes independientes del Anábuac, llamado por los españoles Nueva-España, impresa en Filadelfia, por Juan F. Hurtel, 1821.

Moncure Conway, Daniel (ed.), The Writings of Thomas Paine, Nueva York y Londres, G. P. Putnam's Sons, 1894-1895, 3 volúmenes.

Moscovici, Serge y Hewstone Miles, "De la ciencia al sentido común”, en Moscovici (comp.), 1985, pp. 679-710.

Moscovici, Serge (comp.), Psicología social, II. Pensamiento y vida social. Psicología social y problemas sociales, Barcelona, Paidós, 1985.

Myers, Jorge, "El letrado patriota: los hombres de letras hispanoamericanos en la encrucijada del colapso del imperio español en América", en Altamirano, 2008, vol. I, pp. 121-144. 
Nelson, Craig, Thomas Paine. Enlightenment, Revolution, and the Birth of Modern Nations, Nueva York, Penguin Books, 2006, edición electrónica.

Ocampo, Emilio, "La influencia extranjera en la formación de Estados Nacionales en América Latina. El rol de la masonería en el proceso de la independencia”, en Espacio Regional, II: 7 (julio-diciembre 2010), pp. 69-85. https://dialnet.unirioja.es/descarga/articulo/3675427.pdf. Consultado el 29 de noviembre de 2016.

O’Gorman, Edmundo, “Prólogo”, Servando Teresa de Mier. Ideario político, Caracas, Biblioteca Ayacucho, 1978, pp. ix-xxxiv.

Ortega y Media, Juan y Rosa Camelo (coords.), El surgimiento de la historiografía nacional, México, Universidad Nacional Autónoma de México, 1997.

Ortuño Martínez, Manuel, "Hispanoamericanos en Londres a comienzos del siglo XIX”, en Espacio, tiempo y forma, 12 (1999), pp. 45-72.

Ortuño Martínez, Manuel, "Recuperación de Xavier Mina”, en Historia Nova, Revista de Historia Contemporánea en linea, 3 (2003), pp. 94-102.

Paine, Thomas, "Cupid and Hymen”, abril de 1775, Pennsylvania Magazine, en Moncure Conway, 1894, vol. I, pp. 36-39.

Paine, Thomas, “A Dream Interpreted”, mayo de 1775, Pennsylvania Magazine, en Moncure Conway, 1894, vol. I, pp. 48-50.

Paine, Thomas, “Common Sense”, en Foner (ed.), 1955, pp. 5-59.

Paine, Thomas, “Letter to Henry Laurens”, 1778, en Foner (ed.), 1955, p. 211.

Paine, Thomas, "Letter to the Abbé Sieyès", 8 de julio de 1791, en Foner (ed.), 1955, pp. 381-382.

Paine, Thomas, "To the Authors of «Le Républicain»", en Moncure Conway (ed.), 1895, vol. III, pp. 4-8.

Paine, Thomas, "Thomas Paine to the Citizens of the United States", Letter I, November $15^{\text {th }} 1802$, National Intelligencer, en Moncure Conway (ed.), 1895, vol. III, pp. 381-391.

Paine, Thomas, “The Age of Reason”, en Foner (ed.), 1955, pp. 663-830.

Palti, Elías José, La invención de una legitimidad. Razón y retórica en el pensamiento mexicano del siglo XIX (un estudio sobre las formas del discurso político), México, Fondo de Cultura Económica, 2005. 
Palti, Elías, "De la historia de las 'ideas' a la historia de los 'lenguajes políticos'. Las escuelas recientes de análisis conceptual. El panorama latinoamericano", en Anales, 7 y 8 (2005), pp. 63-82.

Perea, Héctor, Los respectivos alientos, México, Universidad Nacional Autónoma de México, 2006.

Pereila Martos, Pilar, "La pérdida del Sentido Común en Hannah Arendt", en Debates sobre las Antropologías. Thémata [en línea], 35 (2005). Consultado el 26 de mayo de 2015, pp. 427-434.

Pisarello, Gerardo, "Vindicación de Thomas Paine", en Revista de Estudios Políticos, 105 (jul.-sep. 1999), pp. 233-263.

Pocock, J. G. A., El momento maquiavélico. El pensamiento político florentino y la tradición republicana atlántica, Madrid, Tecnos, 2008.

Pocock, J. G. A., La Ancient Constitution y el derecho feudal, Madrid, Tecnos, 2011.

Rieu-Millan, Marie Laure, Los diputados americanos en las Cortes de Cádiz, Madrid, Consejo Superior de Investigaciones Científicas, 1990.

Rivas Granados, Eduardo, "Influencia del pensamiento político norteamericano en el proceso insurgente y de construcción del Estado nacional durante la primera mitad del siglo XIX", tesis de maestría en historia, Puebla, Benemérita Universidad Autónoma de Puebla, 2014.

Rodríguez Cascante, Francisco, “Tierno Galván, Francisco, Bajtín y el pensamiento dialógico", en Revista Comunicación, 12: 1 (2002), pp. 1-22.

Rodríguez O., Jaime E., "Introducción”, Servando Teresa de Mier. La formación de un republicano, México, Universidad Nacional Autónoma de México, 1988, Obras Completas, vol. Iv, pp. 7-30.

Rodríguez O., Jaime E., "From Royal Subject to Republican Citizen: the Role of the Autonomists in the Independence of Mexico", en Rodríguez O. (coord.), 1989, pp. 19-43.

Rodríguez O., Jaime (coord.), The Independence, of Mexico and the Creation of the New Nation, Los Ángeles, Universidad de California, Latin American Center Publications, 1989.

Rojas, Rafael, "Traductores de la libertad: el americanismo de los primeros republicanos", en Altamirano (dir.), 2008, pp. 205-226.

Rosenfeld, Sophia, Common Sense: a Political History, Cambridge, Harvard University Press, 2011. 
Saint Lu, A. y M. C. BÉnassy-Berling (coords.), Historia de la revolución de Nueva España. Fray Servando Teresa de Mier. Edición crítica, París, Publications de la Sorbonne, 1990.

Seaman, John W., "Thomas Paine: Ransom, Civil Peace, and the Natural Right to Welfare", en Political Theory, 16: 1 (1988), pp. 120-142. http://www.jstor. org/stable/191650. Consultado el 25 de abril de 2012.

Shapiro, Ian y Jane E. Calvert (eds.), Selected Writings of Thomas Paine, New Haven y Londres, Yale University Press, Rethinking the Western Tradition Series, 2014, edición electrónica.

Silva Beauregard, Paulette, "Redactores, lectores y opinión pública en Venezuela a finales del periodo colonial e inicios de la Independencia (1808-1812)", en Altamirano (dir.), 2008, pp. 145-167.

Solé, Jacques, Las revoluciones de fin del siglo XVIII en América y en Europa, México, Siglo Veintiuno editores, 2008.

Soto Ramírez, Juan, "Sentido común y vida cotidiana”, en Casa del Tiempo, [en línea], I: 9 (jul. 2008). Consultado el 5 de octubre de 2014, pp. 63-66.

Tecuanhuey S., Alicia y Carlos Eduardo Rivas Granados, "El discurso republicano de los insurgentes. México, 1813-1824", en Elementos, Ciencia y Cultura, 22: 97 (ene.-mar. 2015), pp. 35-43.

Tilly, Charles, Los movimientos sociales, 1768-2008. Desde sus orígenes a Facebook, Barcelona, Crítica, 2010.

Toland, John (ed.), The Oceana of James Harrington and his Other Works, Dublín, R. Reilly, 1737.

TRenchard, John y Thomas Gordon, "Cato's Letters", en Ronald Hamowy (ed.), Cato's Letters or Essays on Liberty, Civil and Religious, and Other Important Subjects, Indianapolis, Liberty Fund, 1995, vol. 4. Online Liberty Fund, http://oll.libertyfund.org/titles/trenchard-catos-letters-vol-4-december-8-1722-to-december-7-1723-lf-ed. Consultado el 2 de octubre de 2015.

VATTEL, Emer de, El derecho de gentes o principios de la ley natural aplicados a la conducta y a los negocios de las naciones y de los soberanos, traducido por el licenciado don Manuel Pascual Hernández, individuo del Ilustre Colegio de Abogados de esta Corte, Madrid, Imprenta de Sandra, 1820.

Vickers, Vikki J., My Pen and my Soul Have Ever Gone Together, Nueva York, Taylor \& Francis Group, 2006, edición electrónica.

Vovelle, Michel, El hombre de la Ilustración, Madrid, Alianza Editorial, 1992. 
Wobeser, Gisela von, "La Consolidación de Vales Reales como antecedente de la lucha de independencia (1804-1808)”, en MAYER (coord.), 2007, pp. 15-28.

Zárate Toscano, Verónica, Juan López de Cancelada. Sucesos de Nueva España hasta la coronación de Iturbide, México, Universidad Nacional Autónoma de México, 2008 (Estudio Introductorio), pp. 25-59. 